\title{
OLMEC CRAYFISH FARMING
}

\author{
Brian Stross \\ The University of Texas
}

\section{Introduction}

The Olmecs of Early and Middle Formative times were responsible for constructing the earliest civilization in Mesoamerica. They influenced later Mesoamerican civilizations in ways that can be seen in iconography, calendrics, epigraphy, town planning, architecture, and loan words, as well as in myriad ways that are not so easily traceable. Major Olmec sites, such as San Lorenzo, La Venta, Laguna de los Cerros, Chalcatzingo, and Teopantecuanitlan were actively occupied for varying periods between approximately 1400 and 300 B.C. Although Teopantecuanitlan is located in Guerrero and Chalcatzingo is in Morelos, what is known as the "Olmec heartland" is focused on the northem part of the Isthmus of Tehuantepec, in southem Veracruz and westem Tabasco (Fig. 1). Olmecs are believed by some scholars to have spoken a Mayan language. Others, basing their opinions on language distribution, loan words, and physical types in local populations, think that the Olmecs spoke a Mixe-Zoquean language.

This paper intends to make three contentions and to argue their correctness. The first is that the Olmecs, or at least some of them, felt crustaceans, and particularly crayfish, to be important economically, symbolically, and perhaps in some other ways as well. 


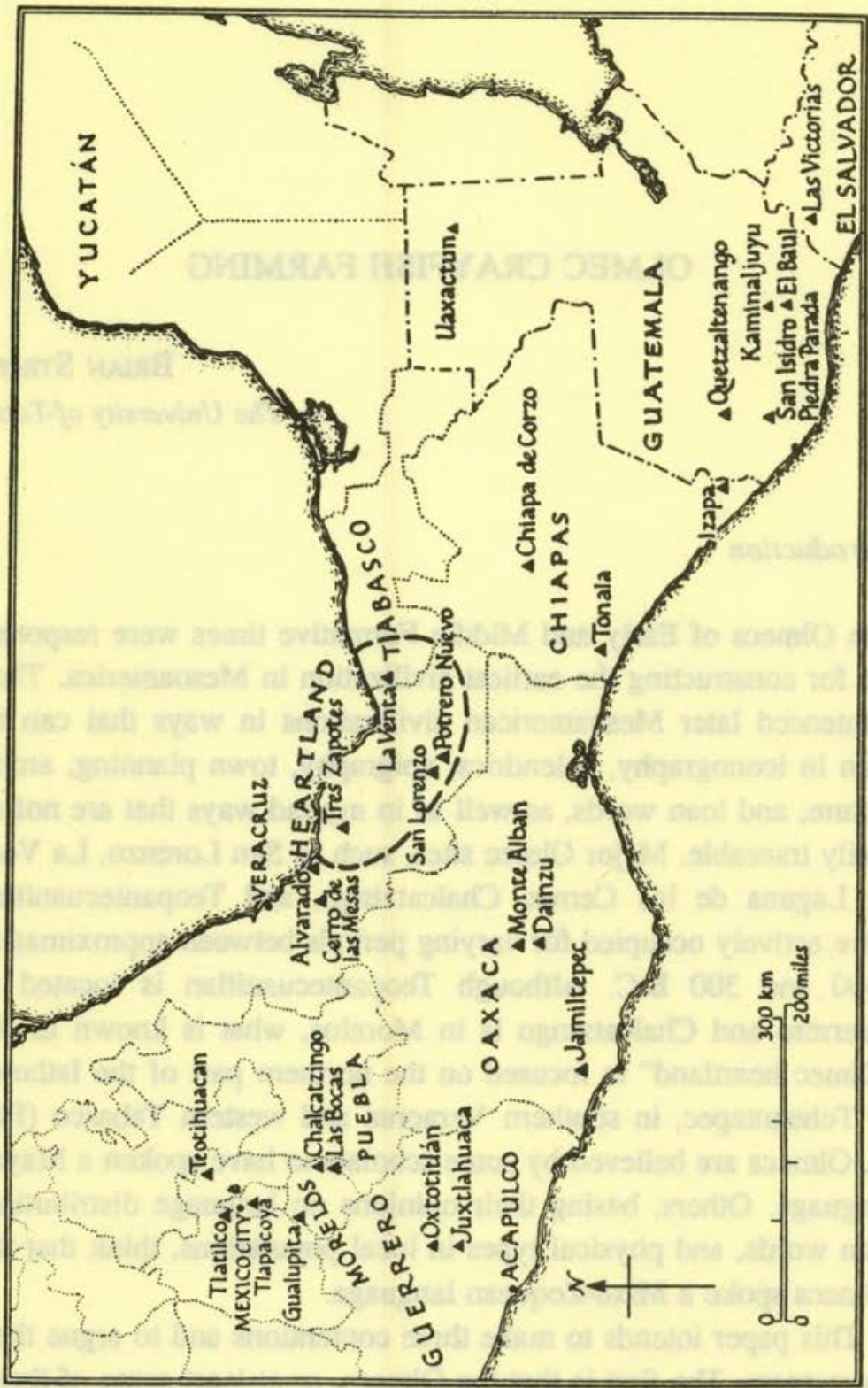

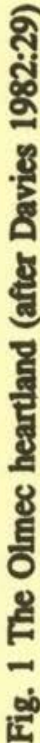


Iconographic and linguistic evidence supporting this thesis is presented. ${ }^{1}$

Second, evidence supporting the first contention also supports the hypothesis that the Olmecs spoke a Mixe-Zoquean and not a Mayan language. That is to say, Mixe-Zoqueans are descendants of the Olmecs.

Third, the ecology of the Olmec heartland and features of at least some Olmec sites are consistent with the hypothesis that Olmecs practiced crayfish farming and perhaps can even be best explained in terms of such practices. This hypothesis is strongly supported by the first contention involving evidence of the importance to Olmecs of the crayfish and other crustaceans. but the other evidence is more equivocal in its interpretive capabilities. It is presented here as a motivated hypothesis, not contradicted by a consideration the evidence, that can indeed be seen as consistent with it, and that is thus worthy of further investigation.

The swampy, tropical, humid Olmec heartland, with its year round agricultural potential and its seasonal flooding of grassy pasturelands, is highly fertile and productive land supporting rich harvests of several kinds of food crops (including maize, beans, squash, sweet potatoes, manioc, and malangas) as well as being the habitat of fish, crustaceans, aquatic birds, deer, and other animals of potential food value.

In several respects the Olmec heartland ecologically resembles the seasonally flooded swampy lowland Atchafalaya river basin of south central Louisiana, North America's most important source

1 Thanks are due James Garber, who first suggested to me the idea of crayfish farming, in response to my conclusion that the Olmecs placed much importance on the crayfish. Mixe-Zoquean lexical sources used in this paper are Clark and Clark (1974), Clark (1981), Schoenhals (1965), Van Haitsma (1976), and Harrison et al. (1981). For Mayan words, sources include Swadesh et al. (1966), Aulie and Aulie (1978), Edmonson (1965), Laughlin (1975), and Slocum and Gerdel (1965). The orthography employed herein is a normalized phonemic one, deviating from Amerindianist practice in that $A$ stands for shwa (the mid-central vowel), and $c h$ stands for the dental affricate $c$. Herein also, $x$ indicates the post-alveolar voiceless groove fricative (or sibilant) known as "esh", while $j$ indicates the vioceless velar fricative that in the IPA is given as $\boldsymbol{x}$. In this convention, I am closely following practices of Mayanists. 
of crayfish. Furthermore, in the Olmec heartland "several kinds of shrimp and crayfish, all called camarones, are known and collected" (Coe and Diehl 1980:120), even today.

In Louisiana, outside the Atchafalaya river basin system, more than 100,000 acres of constructed and managed crayfish ponds supplement the "wild" crayfish catch, allowing for consistent and earlier crayfish harvests (Moody 1985:2). In the Olmec heartland crayfish farming could have provided a rich source of protein, highly valued for its taste, to supplement root crops and/or maize for support of the substantial local population and complex social organization characterizing Olmec civilization. Just such an economic motive could help to explain the strong Olmec interest shown in the crayfish that can be inferred from the testimony of Olmec language and iconography.

Central, but not alone in this testimony, is the forehead ornament of a deity represented on an Olmec vessel. It is here identified as a crayfish. The identification is substantiated with iconographic, epigraphic, and linguistic evidence, providing a rather compelling case. The crayfish (and shrimp) are seen to have been important to the Olmecs during-some period in their history; so important that traces can be found in contemporary Mixe-Zoquean languages and in neighboring Mayan languages as well as in the Classic Maya script. These traces provide additional evidence that at least some of the Olmecs spoke a Mixe-Zoquean language, and that they had an impact on Mayan cultures. Some aspects of crayfish farming as currently practiced in Louisiana and Texas are outlined in order to provide explanatory ethnographic analogy.

\section{Iconography}

Chalcatzingo is an "Olmec" site in the Morelos highlands south of Mexico City (Fig. 1), known especially for its huge relief murals on rock, and it is also the location of origin for a large um depicting the disembodied head of a deity, perhaps a maize or fertility deity. This um from Chalcatzingo provides the most detailed view 
of a forehead omament that is found in more stylized versions on other examples of Olmec portable art (Fig. 2a). The forehead omament found on this large cone shaped um rather closely resembles the edible portion of a crayfish or similar crustacean when compared to other such representations (Fig. 2b).

A somewhat less naturalistic depiction of the same forehead omament is found on an Olmec celt of unknown provenience that can be seen in Fig. 3. More abstract still is the forehead omament on a celt from Tlaltenco (Fig. 4). This last version shows the forehead omament to consist of three essential parts. The bottom is a dotted circlet, the middle is a small number of horizontal lines surmounting the circlet, and the top is a vertically oriented bifurcation. These stylized forms can be seen in more detail and more representationally on the Chalcatzingo um's forehead omament, where one can make out both legs and platelets of the crayfish depicted. In sum, the forehead ornament looks like a crayfish.

The forehead omament represented on the Middle Preclassic Olmec urn closely resembles in structural position, and in its tripartite form (with a circlet surmounted by horizontal and vertical elements), a similar forehead omament found in the Classic Maya glyphic script on the head of a raptorial bird (glyph T747b of the Maya script; Fig. 5). ${ }^{2}$ Furthermore the disembodied deity head of the Olmec um has a downcurved beaklike protuberance in the upper lip area that arguably represents the beak of a raptorial bird. ${ }^{3}$ Even today, in Chol Mayan, one of closest living representatives of the language of the Classic Maya glyphs, a word for the raptorial hawk is literally "shrimp hom". 4 This Chol name for the hawk

2 This bird is currently identified as a vulture, although it has also been seen as an eagle or a hawk.

${ }^{3}$ Some observers interpret this protuberance as a shark's tooth, relating it to other elements of bloodletting iconography repertoire.

4 The shrimp and crayfish, though differing somewhat in shape are closely related in the cognition of some of the occupants of Mixe-Zoquean and Mayan regions. The same word, for example means either 'crayfish' or 'shrimp', depending on the dialect of Tzeltal or Tzotzil (Mayan) referred to. In Sayula and Oluta Popoluca the difference between words for these crustaceans is a matter of a qualifier added to the noun referencing both. And we have seen above that 


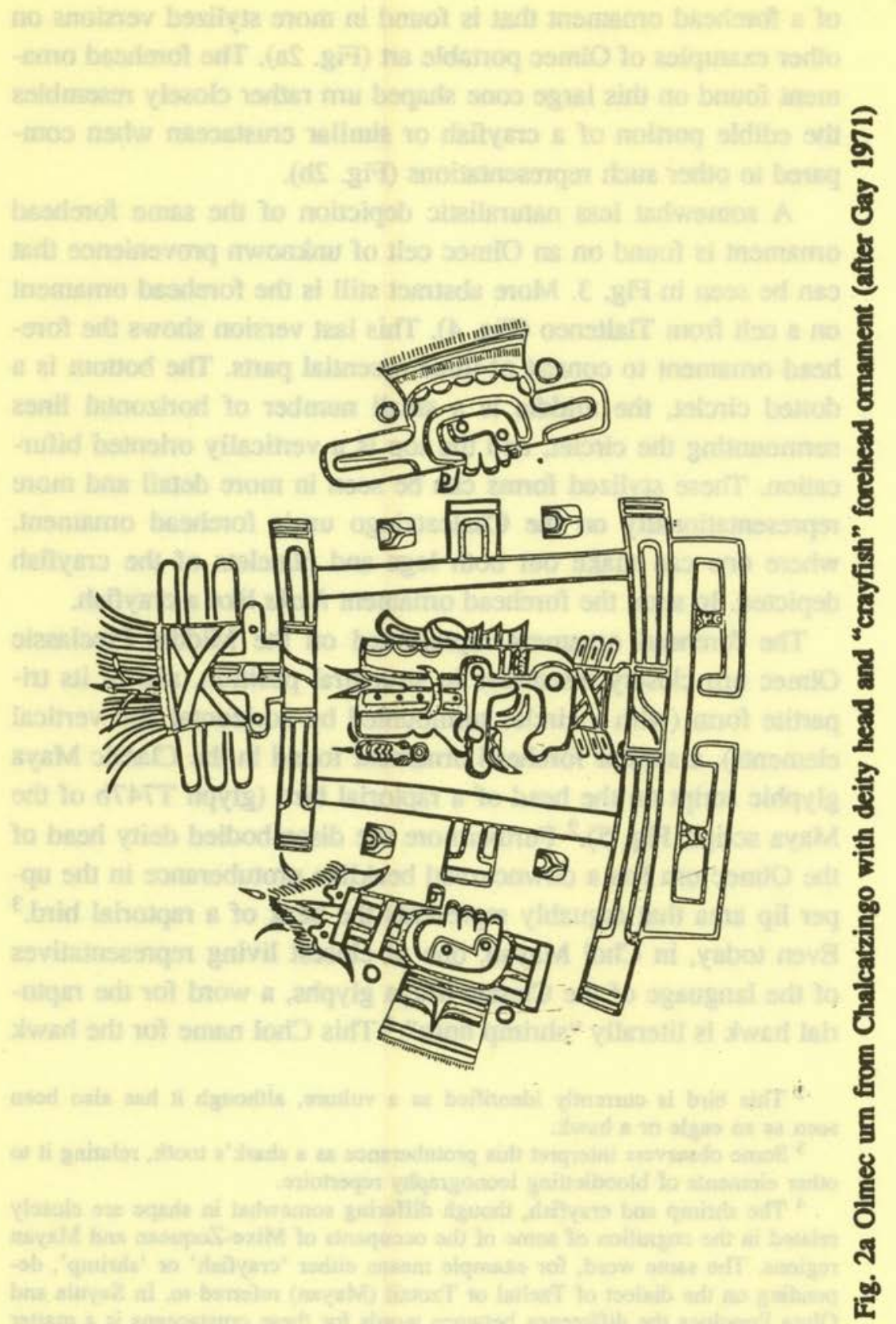




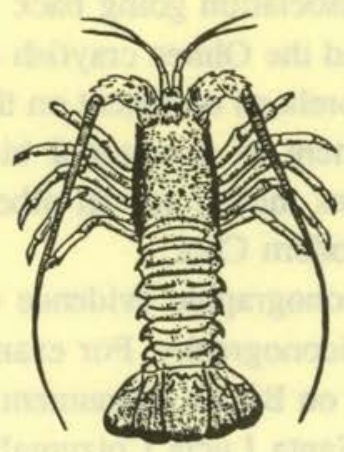

Fig. $2 \mathrm{~b}$ from left to right, shrimp, crayfish, and spiny lobster (after Hamison and Harrison 1981:273)

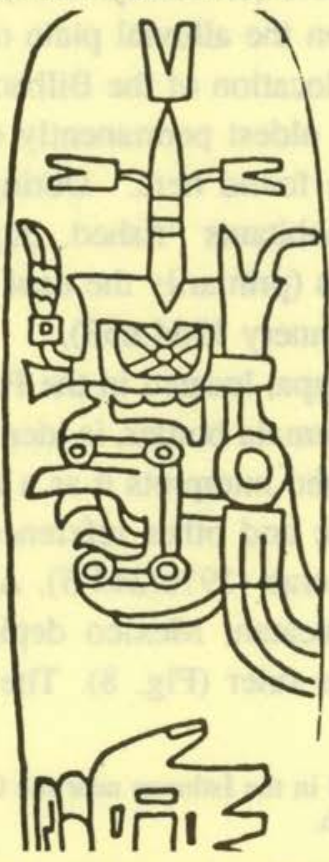

Fig. 3 Olmec celt of unknown provenience (after Covamubias 1957:
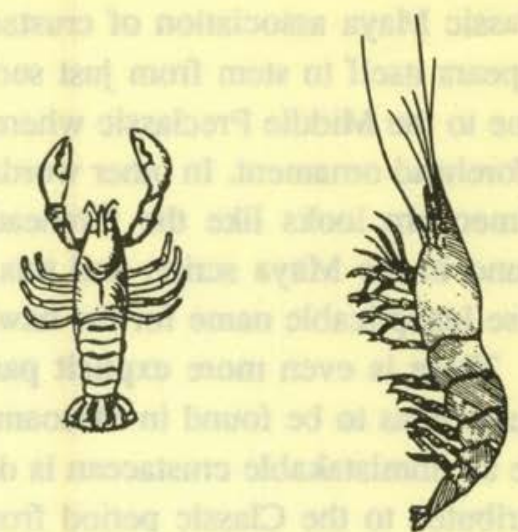

Fig. 33)

Estudios de Cultura Maya. Vol. XIX, 1992

Instituto de Investigaciones Filológicas/

Centro de Estudios Mayas, UNAM

ISSN 0185-2574

Fig. 4 Olmec celt from Tlaltenco (after Joralemon 1971: Fig. 34) 
is inexplicable unless it harkens back to a Classic Maya association of a raptor with a crustacean forehead omament. And the Classic Maya association of crustacean with a forehead ornament appears itself to stem from just such an association going back in time to the Middle Preclassic where we find the Olmec crayfish as a forehead omament. In other words, the forehead omament on the Olmec um looks like the forehead ornament of a raptorial bird found in the Maya script, and this provides motive for an otherwise inexplicable name for the hawk in Modem Chol.

There is even more explicit parallel iconographic evidence of crustaceans to be found in Mesoamerican iconography. For example an unmistakable crustacean is depicted on Bilbao Monument 1 attributed to the Classic period from the Santa Lucia Cotzumalhuapa area of Pacific coastal Guatemala. It is a crab; and it rests atop the head of the person depicted on the monument (Fig. 6). If the monument indeed bears religious symbols as it appears to, then the notion that the religion of a culture reflects the environment of the society is aptly evidenced here (cf. Reilly 1987). The estuarine microenvironment near Ocos on the alluvial plain of the Pacific coast of Guatemala, the general location of the Bilbao culture, is rich in wild foods. Some of the oldest permanently occupied villages in Mesoamerica are to be found here. During the Cuadros phase (1000-850 BC) the inhabitants "fished, dug for marsh clams, and above all, caught crabs (primarily the azul crab, which is trapped at night)" (Coe and Flannery 1964:653).

A late Preclassic zoomorph altar at Izapa, located in the Pacific coast piedmont of Chiapas near the Guatemala border, is identified as a realistic crab by Norman (Fig. 7), who interprets it as a fertility symbol, citing Mesoamerican mythic and other references as evidence for fertility associations of the crab (1976:244-5). A jade from the cenote at Chichen Itza in Yucatan, Mexico depicts a huge crab upon which stands a deity or ruler (Fig. 8). The jade

camarón is the Spanish term currently employed in the Isthmus near the Olmec site of San Lorenzo for both shrimp and crayfish. 


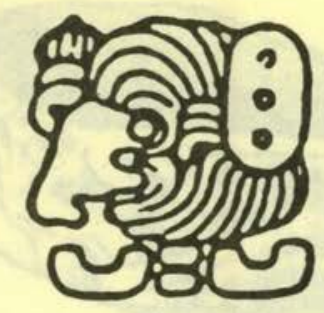

\section{0}

Fig. 5 T747b of the Maya script

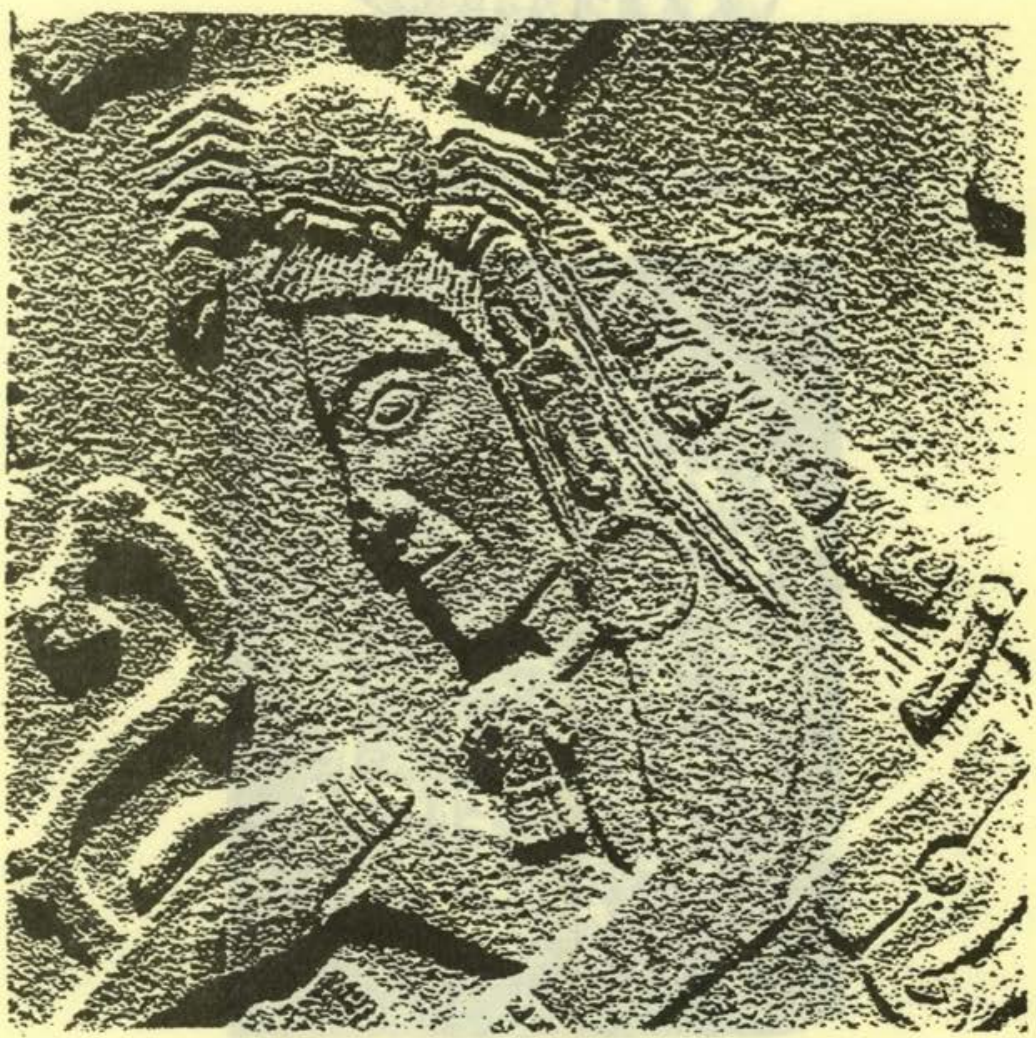

Fig. 6 Bilbao Monument 1, (note crab on head) 


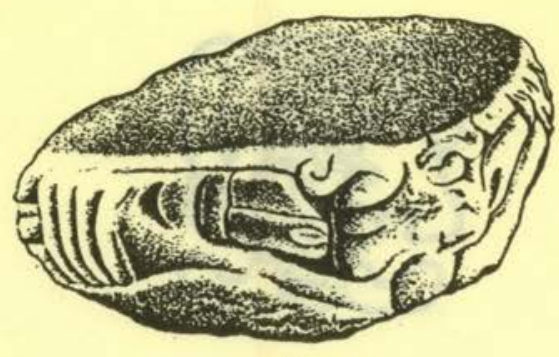

a

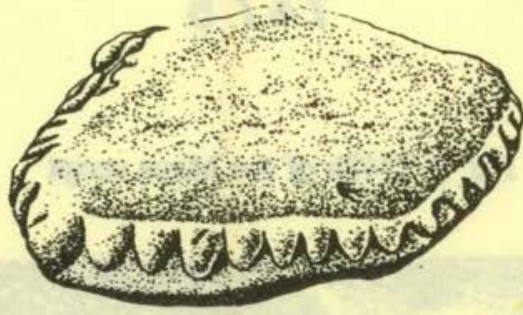

Fig. 7 Crab altar at Izapa (After Norman 1976:245)

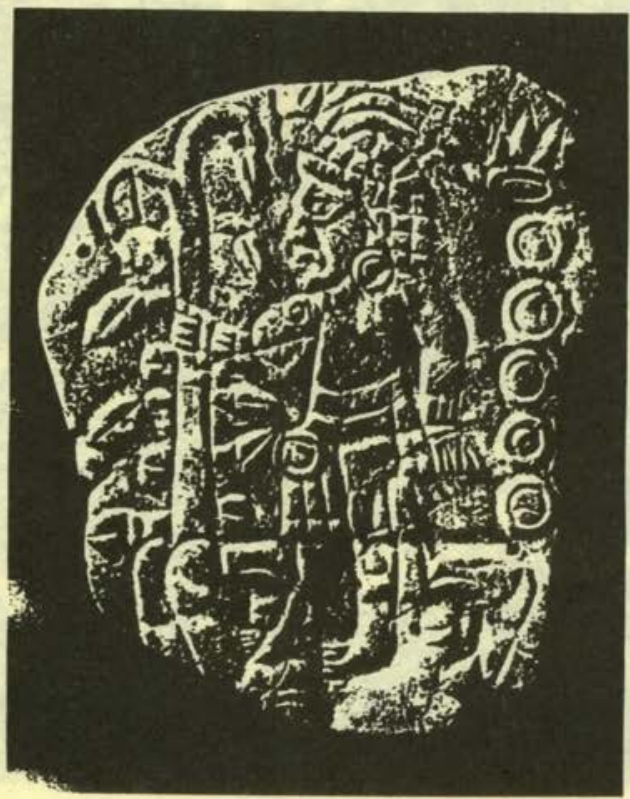

Fig. 8 Crab as earth from Chichen Itra (after Coggins and Shane 1984:59) 
has been attributed to Terminal Classic times and is identified as coming originally from the Pacific coast, which is where the Bilbao culture is located (Coggins and Shane 1984:59).

The Classic Maya themselves are known to have had some iconographic interest in crustaceans, as evidenced in the Bonampak murals of Chiapas where human individuals are dressed as crabs or crayfish (Fig. 9); and we find Costa Ricans depicting realistically the crayfish (Fig. 10) and the spiny lobster (Fig. 11) in gold. Even up in the valley of Oaxaca, Mexico, the Lapida Bazan shows "sky jaws" with stalked eyes and crustacean-like arms suggesting a crustacean model for the representation (Fig. 12).

To summarize:, a) on the Chalcatzingo um the forehead omament looks like a crayfish when compared with other representations of crayfish; b) the forehead omament looks like the forehead omament of what is currently interpreted as a vulture in the Maya script; and c) crustaceans are depicted elsewhere in Mesoamerica at various times, and are even depicted as a forehead omament. At least one crustacean has been interpreted as a fertility symbol. The crayfish, one of several crustaceans depicted and eaten by Mesoamericans could thus have been of considerable significance to the Olmecs, possibly relating to fertility, and is the apparent referent of a forehead omament portrayed on the Chalcatzingo um.

\section{Epigraphy}

Although the iconographic evidence for a crayfish identification on the Olmec um and for the importance of crustaceans to some Mesoamericans is substantial, there may yet remain some doubts about the importance of the crayfish to the Olmecs themselves. Another approach, a small detour focusing on Maya epigraphy, can be helpful in this respect. It is a helpful, but not a necessary, link in the argument conceming the crayfish's importance to the Olmecs, however. This approach is one of tracing an element of the Classic Maya Script to its iconographic source in an Olmec word. 


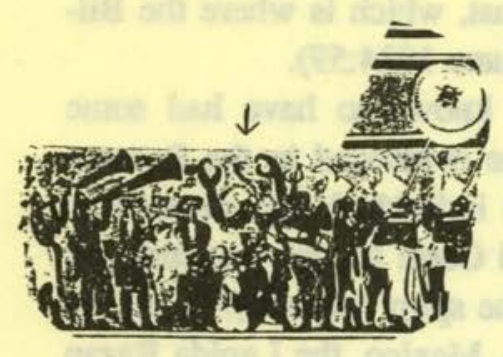

Fig. 9 Classic Maya crab or crayfish representation at Bonampak, Chiapas

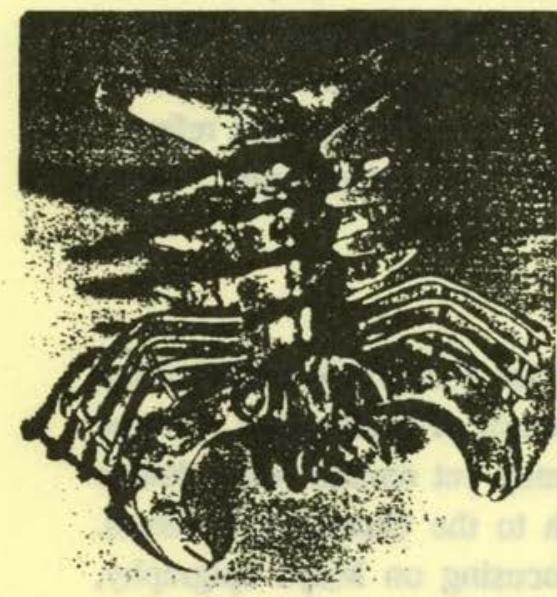

Fig. 10 Gold crayfish pendant from Costa Rica, $8 \mathrm{~cm}$. (After Attenborough 1976:58)

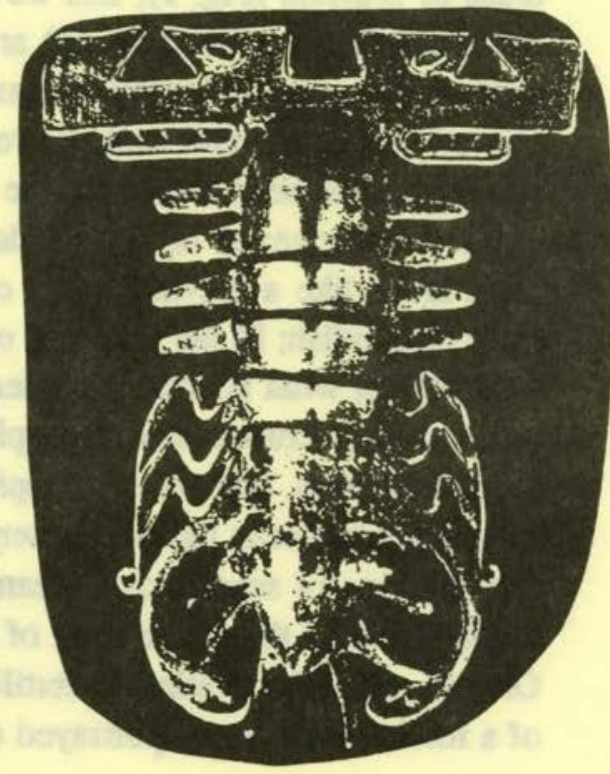

Fig. 11 Gold spiny lobster pendant from Costa Rica. 
The latest manifestation of the element is in an early Colonial "alphabet" of Diego de Landa, where sound values are given to a number of Postclassic Maya glyphs (Fig. 13), many of which can be traced to Classic Maya times. The specific one under consideration here can be found in Early Classic and even Late Preclassic Maya contexts. It is Landa's second $\mathrm{O}$, quite similar it may be noted, to Landa's first $O$.

Landa's second $\mathrm{O}$, with a phonetic value of /o/ or perhaps /oy/ is virtually identical to a Postclassic variant (found in the Maya Codices), and quite similar to the Classic variants of the glyph given the number T59 in reference to Thompson's (1962) catalog (Fig. 14). T59, though more closely resembling Landa's second O, is known to have a phonetic value of $\mid t i /$, or $\mid t a /$ in the Maya script and is therefore identified by epigraphers as Landa's $t i$, which is given as part of a sentence supplementing his "alphabet" (cf. Fig. 13). Landa's "alphabet" indicates that it may also represent phonetic /o/ or /oy/, but contexts where it might have this value have not been identified by epigraphers. ${ }^{5}$

T59 is the precise forehead ornament of the raptorial bird of the Maya script mentioned above (Fig. 5). It functions in the Maya script as a general preposition (ie. to, in, on, at), and it apparently has the same sound value and grammatical function as the glyphs known as T51 and T53 (Fig. 15) (Mathews and Justeson 1984:203). T51 or a glyph identical to it can be seen on the Dumbarton Oaks jade plaque (Fig. 16), which carries examples of a precursor script to that of the Classic Maya. This glyph can be compared to the depiction in Olmec iconographic tradition of the forehead omament on the Olmec celt of Fig. 17, which, it has been suggested above, is a conventionalized abstraction of the forhead omament on the Olmec um from Chalcatzingo.

5 This is not the case with Landa's first $O$, however, which has been equated with T99 and found to represent the sound $o c$ (Justeson 1984:323) in the Postclassic codices. For example, on Dresden 9b, the collocation T99:533 substitutes for the normal version of the numeral 'three' (cf. Yucatec $o x$ 'three'), and T99 provides thus the $o$ (Barbara MacLeod, private communication). 


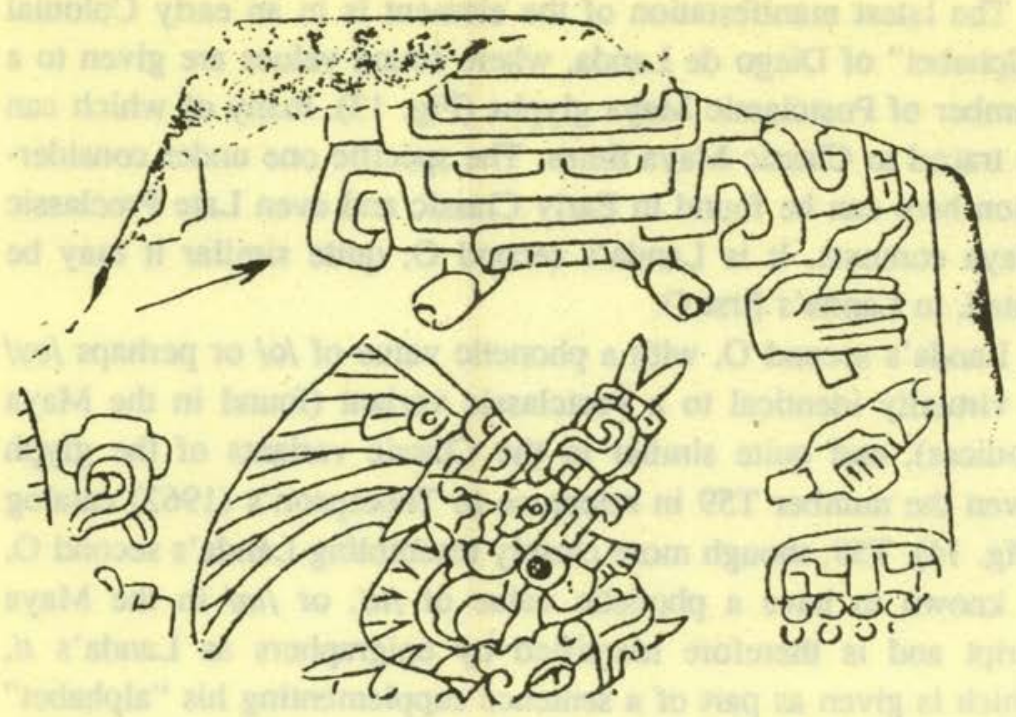

Fig. 12 Lapida de Bazan, from Monte Alban (after Marcus 1980:102)

$$
\begin{aligned}
& \text { mo }
\end{aligned}
$$

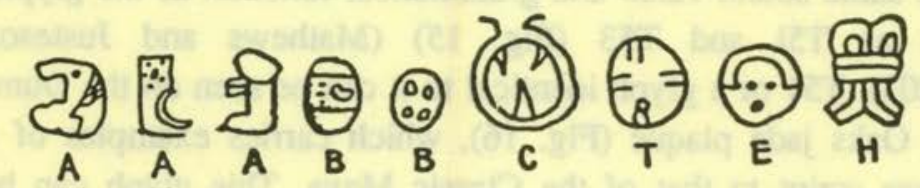

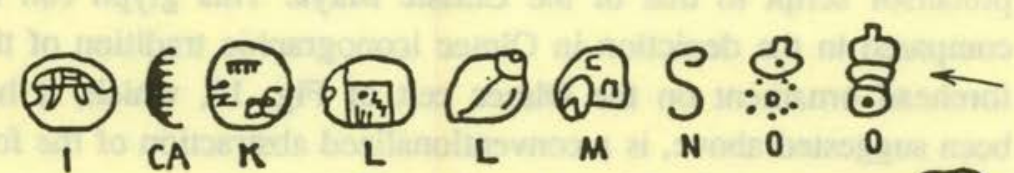

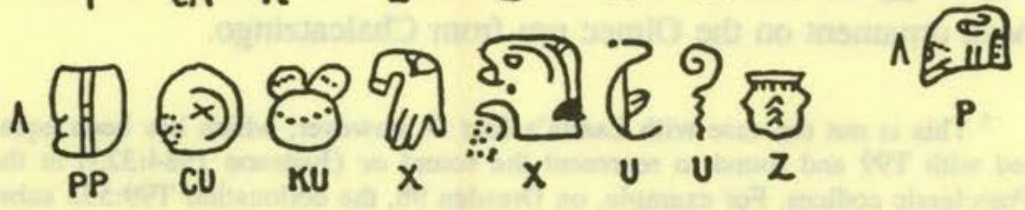

Fig. 13 Landa's "Alphabet" 
It has been argued by means of language distribution and loan words, that the Olmecs are likely to have spoken a Mixe-Zoquean language (Campbell and Kaufman 1976). In Sayula Popoluca, a Mixe-Zoquean language spoken in the Olmec heartland area, the word for 'shrimp/crayfish' is ooy, in Oluta Popoluca it is ooyo. ${ }^{6}$ The Huastec Mayans, living north of the Isthmus of Tehuantepec have a borrowed form oy referring to a species of crayfish living in wells and watery depressions.

If the Olmec word for 'crayfish' was oy or ooy, and if the forehead ornament on the deity of the Chalcatzingo um (and elsewhere in Olmec iconography) is a crayfish (or shrimp), then we seem to have found an iconographic source for T51, T53, and T59 of the Maya script, which may well explain the fact that a sound value of $o$ is attributed by Landa to a glyph that to all appearances is T59, even though T59 is not known to have had that sound value in any Classic period context, and even though a locative/ prepositional grammatical function cannot be associated with that sound value in Cholan or Yucatecan languages. It will be seen shortly, however, that a prepositional function can be associated with that sound value in Mixe-Zoquean languages.

The epigraphic trail beginning with Landa's alphabet, and the $O$ glyph therein, leads backwards in time through the Classic Maya as well as westward in space and back still further in time to an um of Middle Preclassic Olmec vintage. An icon of a crayfish, found as a forehead omament on a disembodied deity head (with possible raptorial features) is postulated to have developed through time and space into multiple Maya glyphs, all resembling the earlier form in slightly different ways, illustrated here (Figs. 5, 13, 14, 15), one of which in early Classic times is the forehead omament of a raptorial bird, although later it also has an independent existence as T59.

${ }^{6}$ Coe and Diehl (p. 120). Specificaly, but no exclusively in the Isthmian area in which the Sayula Popoluca dwell, local inhabitants linguistically lump shrimp and crayfish together. "Several kinds of shrimp and crayfish, all called camarones, are known and collected in the Olmec heartland side of San Lorenzo." (Coe and Diehl 1980:120). 
To clinch the case we must recall the sound value already mentioned in connection with the Popoluca terms for 'crayfish / shrimp'. Reconstructing a Middle Pre-Classic Olmec word for crayfish based on Popoluca, from the Mixean branch of the Mixe-Zoquean language family, we have a posited ProtoMixean *oy 'crayfish' that is suggested here to have developed through time and space into multiple Maya glyphs, one of which in the 16 th century had the phonetic value demonstrably given by Landa as $o$.

\section{Language}

At this point, should there remain any doubts concerning the importance of the crayfish to the Olmecs and later evidences of such importance in Mayan cultures, the following two sorts of linguistic evidence left for last should completely dispel them; (1) rebus potential through homophony, and (2) loan words.

\section{Rebus Capability}

First we must consider the rebus capability of the Olmec crayfish icon, demonstrated through Mixe-Zoquean. Rebus communication takes place when something easier to depict is employed for similar sounding words that are more difficult to represent graphically. A rebus is thus a reference to a word by depicting a homophone of it. It is a written, or visually communicated, pun. Used as a rebus, the depiction of a crayfish could represent, for MixeZoquean speakers but not for Mayans, (l) 'beautiful' ('good', 'noble', 'exalted') (Table I), (2) 'maize' (Table II), or (3) a locative preposition ('to, on, at') (Table III). Such rebus representation is possible in Mixe-Zoquean languages because words for 'crayfish' in these languages are very similar to words for 'beautiful, good, exalted' and 'maize' as well as similar to locative prepositions. 


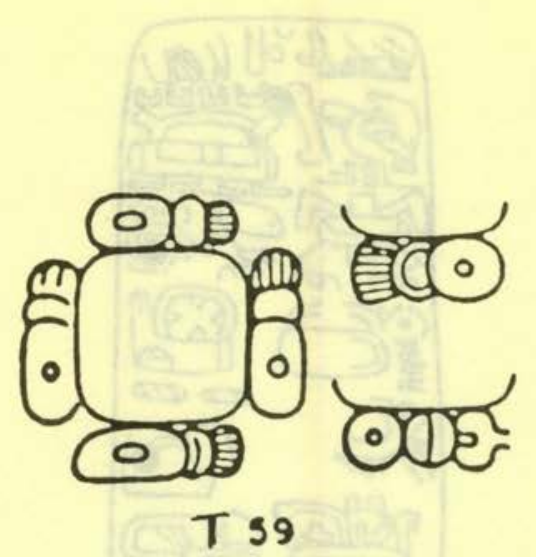

Fig. 14 T59 of Thompson's Catalog
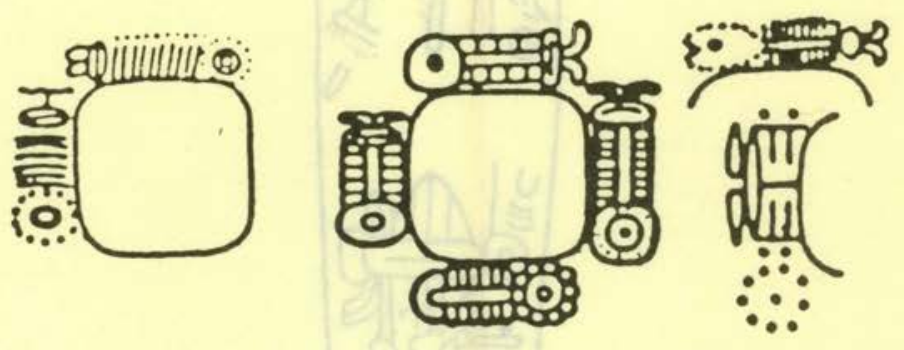

Fig. 15 T51 and T53 of Thompson's Catalog. 


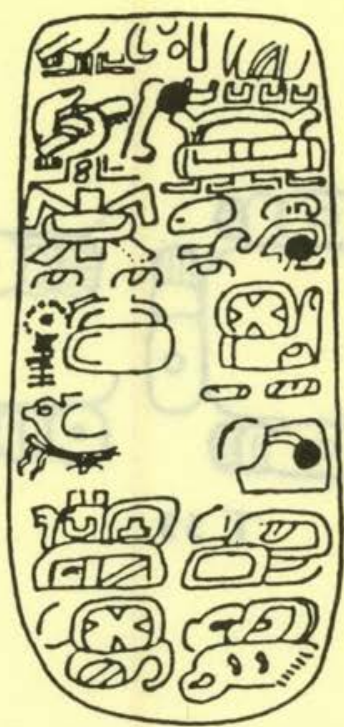

Fig. 16 Dumbarton Oaks jade plaque (after Coe 1976, Fig. 17)

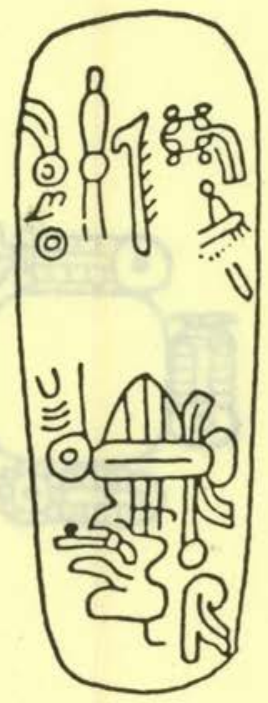

Fig. 17 Olmec celt (after Joralemon 1971: Fig. 34) 
For example Copainala Zoque, of the Zoquean branch of MixeZoquean, has a word sas 'crayfish' that sounds very similar to the Zoque word sa?sa 'beautiful'. The two words are thus near homophones, and a Zoque speaker might draw a picture of a crayfish in order to have another understand it to mean 'beautiful' in the same way that we could depict a bee and a leaf together and have an English speaker read the combination as 'belief'. Sayula Popoluca -a Mixean language spoken in the Olmec heartland area- has a word ooy 'shrimp, crayfish' that is nearly homophonous with oy 'good, fine'. Oluta Popoluca's cognate forms are respectively ooyo 'crayfish' and oya 'good, fine'. In fact, all branches of the MixeZoquean language family have cognates for at least the latter meaning. Totontepec Mixe, for example, has $O y$ 'good, fine, correct' (and also OOy 'very much, a lot; very, extremely' which is derived from it, and which one would expect to be cognate with the 'shrimp, crayfish' word of Popoluca). Copainala Zoque has the cognate form oye 'good, fine' which mirrors a reconstructed Proto-Mixe-Zoquean *oye 'good, fine.'

Totontepec Mixe, representing the Mixean branch of Mixe-Zoquean has a word $k A A$ ? $x m$ 'shrimp' that has a very near homophone in $\mathrm{kAhxm}$ 'exalted, up above, tall, height' and thus a picture of the former could be used for the latter. What is particularly surprising is that we seem to have more than an accidental coincidence linking the crayfish (or shrimp) with excellence. ${ }^{7}$ The near homophony forging that link is not just a single occurrence. On the contrary, it occurs with three different 'shrimp/crayfish' words

7 Given Copainala Zoque kAsmA 'above, high, tall, on top', we can tentatively reconstruct Proto-Mixe-Zoquean *kAAsmA 'high, up above'. The Mixe word for 'shrimp'apparently has no cognate forms in Zoquean languages (unless Zoque kya?s 'eat, bite' is cognate). One can speculate, then, that the Mixe word for shrimp is a later development that could be derivationally related to the word for 'high, up above, exalted' given the fact that these concepts are apparently linked in some way. 
that are completely distinct etymologically in the three representative Mixe-Zoquean groups (see Table I).

\section{TABLE I. CRAYFISH}

$\begin{array}{llc}\text { Zoque } & \begin{array}{l}\text { sas } \\ \text { sa?sa }\end{array} & \begin{array}{c}\text { 'crayfish' } \\ \text { 'beautiful' }\end{array} \\ \begin{array}{lll}\text { Popoluca } & \begin{array}{l}\text { ooy } \\ \text { oy }\end{array} & \text { shrimp/crayfish' } \\ \text { 'good, fine, nice' }\end{array} \\ \begin{array}{llc}\text { Mixe } & \begin{array}{l}k A \text { ? } x m \\ k A h x m\end{array} & \text { 'shrimp' } \\ & \text { 'high, exalted' }\end{array}\end{array}$

It seems highly likely, because of this multiple near homophony, that Mixe-Zoquean languages reflect some cognitive, symbolic, or semantic connection between 'goodness, beauty, or exaltedness' and the crayfish (and/or shrimp), although it is possible that the connection is just between the words for these concepts, just as one would ordinarily take the connection between rebus homophones to be. With or without a cognitive connection, there is a punning (or rebus capability) connection between 'crayfish' and 'good' in Mixe-Zoquean languages, so that the former might stand for the latter. And this particular punning connection is apparently a strong and pervasive one in the Mixe-Zoquean language family.

The conclusion thus seems inescapable that the forehead omament on the Olmec urn from Chalcatzingo is a crayfish being used as a rebus for a concept akin to 'good', 'beautiful', or 'exalted', and that this iconographic rebus usage requires a Mixe-Zoquean language base. The auxiliary justifications here are clear. The ornament (1) looks like a crayfish. (2) It is located in the top front position with respect to the head, where one expects to find iconographic qualifiers relating to goodness, fertility, sovereignty, or nobility. ${ }^{8}$ (3) It occurs in a cultural tradition whose iconography

${ }^{8}$ Fish and maize share more than a symbolic connection with fertility. Taube brings together several references demonstrating an equation between maize 
evidences some continuity of formal characteristics with Maya iconography and script in which the rebus principle is known to be used. (4) It occurs in a socio-cultural tradition whose most likely descendants use punning wordplay.

\section{Maize}

Use of the forehead omament and other kinds of headdress is well documented for the Maya in both iconography and script. It seems clear that headdress elements and forehead omaments are meant as qualifiers for (or statements about) the personage with whom the regalia are associated. Such elements -emblems, decorations, insignia, symbols or paraphernalia of status, high office, or royalty- in Maya headdress iconography include maize and fish. These can be interpreted as representative of positive values at the very least, and perhaps more specifically as indicating fertility, nobility, or both. The maize in particular should be regarded in a fertility context, given its importance in Maya traditions and its clear iconographic relationship to the head, hair, and headdress. A particularly interesting use of maize headdress ornamentation is found on the disembodied head depicted on an Early Classic Maya cache vessel lid associated with bloodletting (Fig. 18). Its general structural similarity to the Chalcatzingo um is noteworthy, as is the apparent homologue to the Chalcatzingo urn's forehead ornament which is here shown atop the head.

Unmistakable maize as headdress insignia occurs also in the Olmec iconographic tradition, as for example on a decorated celt from El Sitio (Fig. 19). Some Olmec forehead omaments have also been interpreted as maize, ornaments such as the supposed

and fish in the traditions of different Mesoamerican societies, including the observation by Girard that "contemporary Chorti Maya identify fish with com" (1986:58). Nor is the connection limited to Mesoamerica. Most Americans will recall the legendary Squanto who showed the Pilgrims how to plant com by putting into each mound a fish along with the corn seeds. 


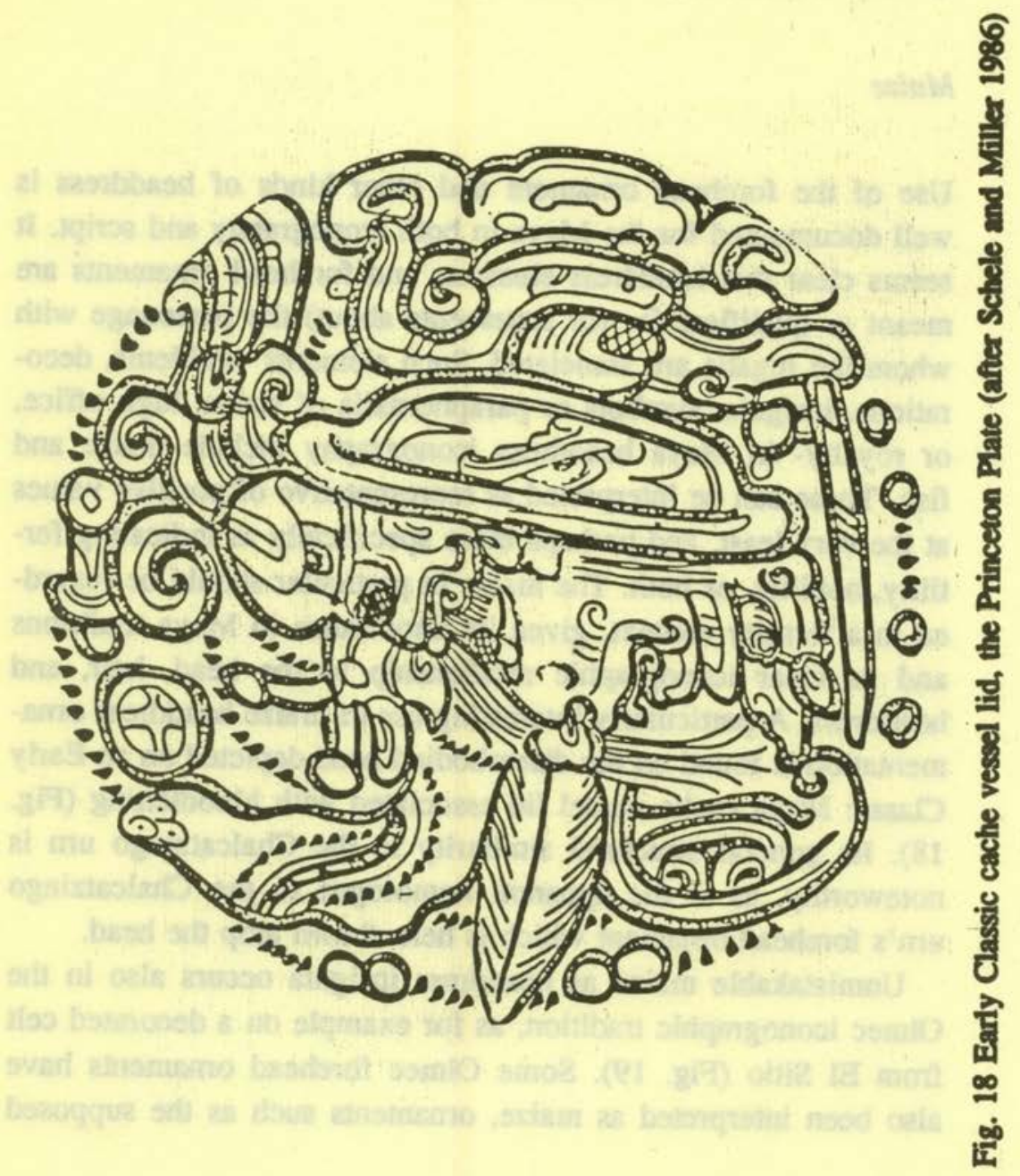




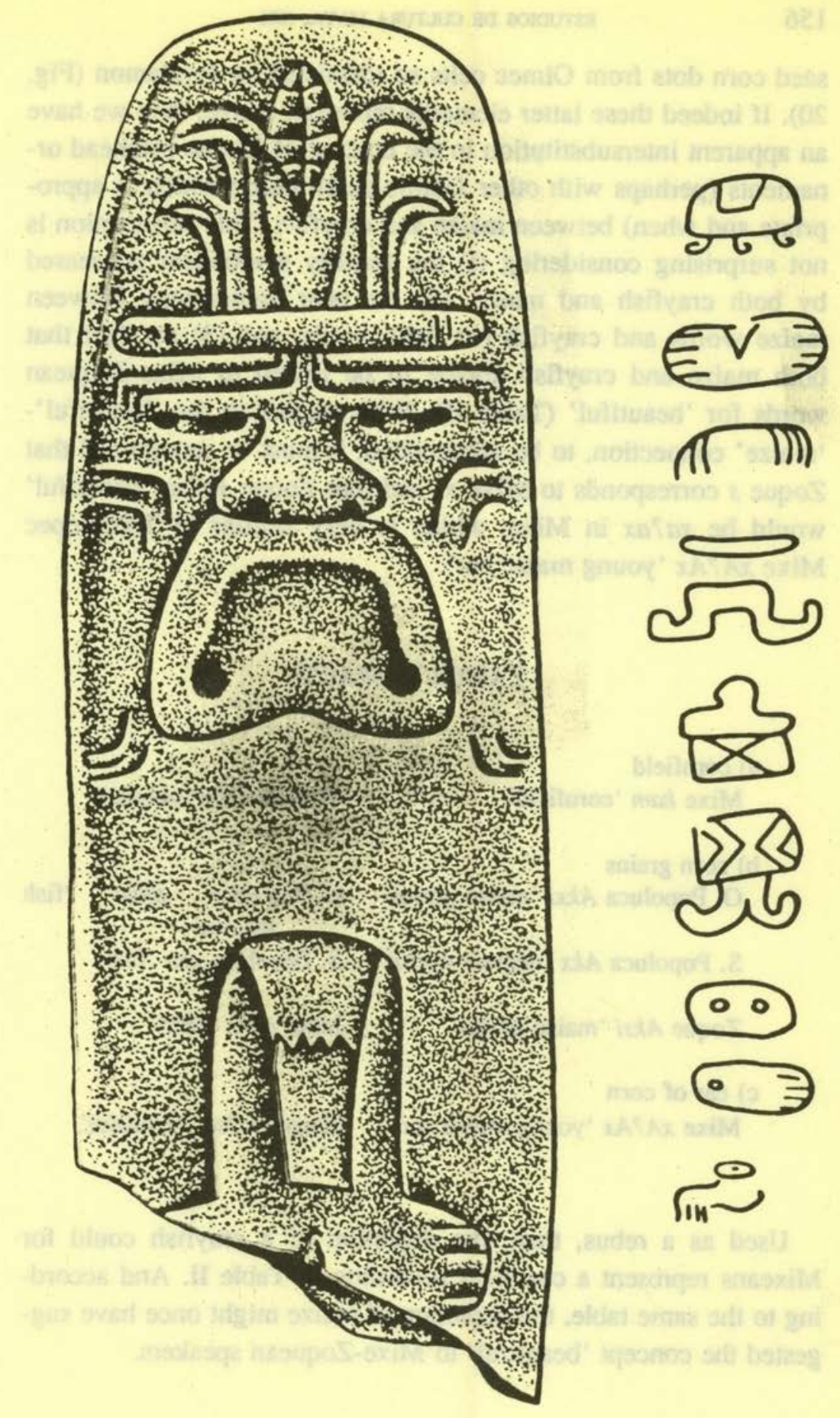

Fig. 19 Celt from El Sitio (after Navarrete 1971:78)

Estudios de Cultura Maya. Vol. XIX, 1992

Instituto de Investigaciones Filológicas/

Centro de Estudios Mayas, UNAM

ISSN 0185-2574 
seed corn dots from Olmec celts so identified by Joralemon (Fig. 20). If indeed these latter elements represent maize, then we have an apparent intersubstitution in the context of Olmec forehead ornaments (perhaps with other factors determining which is appropriate and when) between maize and crayfish. This substitution is not surprising considering (l) the fertility symbolism possessed by both crayfish and maize, (2) the near homophony between maize words and crayfish (or fish) words, and (3) the fact that both maize and crayfish appear to be linked to Mixe-Zoquean words for 'beautiful' (Table II). With respect to the 'beautiful''maize' connection, to be appreciated, it must be recognized that Zoque $s$ corresponds to Mixe $\mathrm{x}$, and that Zoque sa?sa 'beautiful' would be $x a$ ? $a x$ in Mixe, which is very similar to Totontepec Mixe $x A$ ? $A x$ 'young maize ear'.

\section{TABLE II, MAIZE}

a) cornfield

Mixe kam 'cornfield'

Mixe $k A$ ? Am 'crayfish'

b) corn grains

O. Popoluca Akxi 'maize grains'

O. Popoluca akxa 'fish species'

S. Popoluca $A k x$ 'degrain maize'

S. Popoluca $a k x$ 'fish'

Zoque Aksi 'maize grains'

Mixe $a h k x$ 'fish'

c) ear of corn

Mixe $x A$ ? Ax 'young maize ear'

Zoque sa?sa 'beautiful'

Used as a rebus, then, the depiction of a crayfish could for Mixeans represent a cornfield according to Table II. And according to the same table, the depiction of maize might once have suggested the concept 'beautiful' to Mixe-Zoquean speakers. 

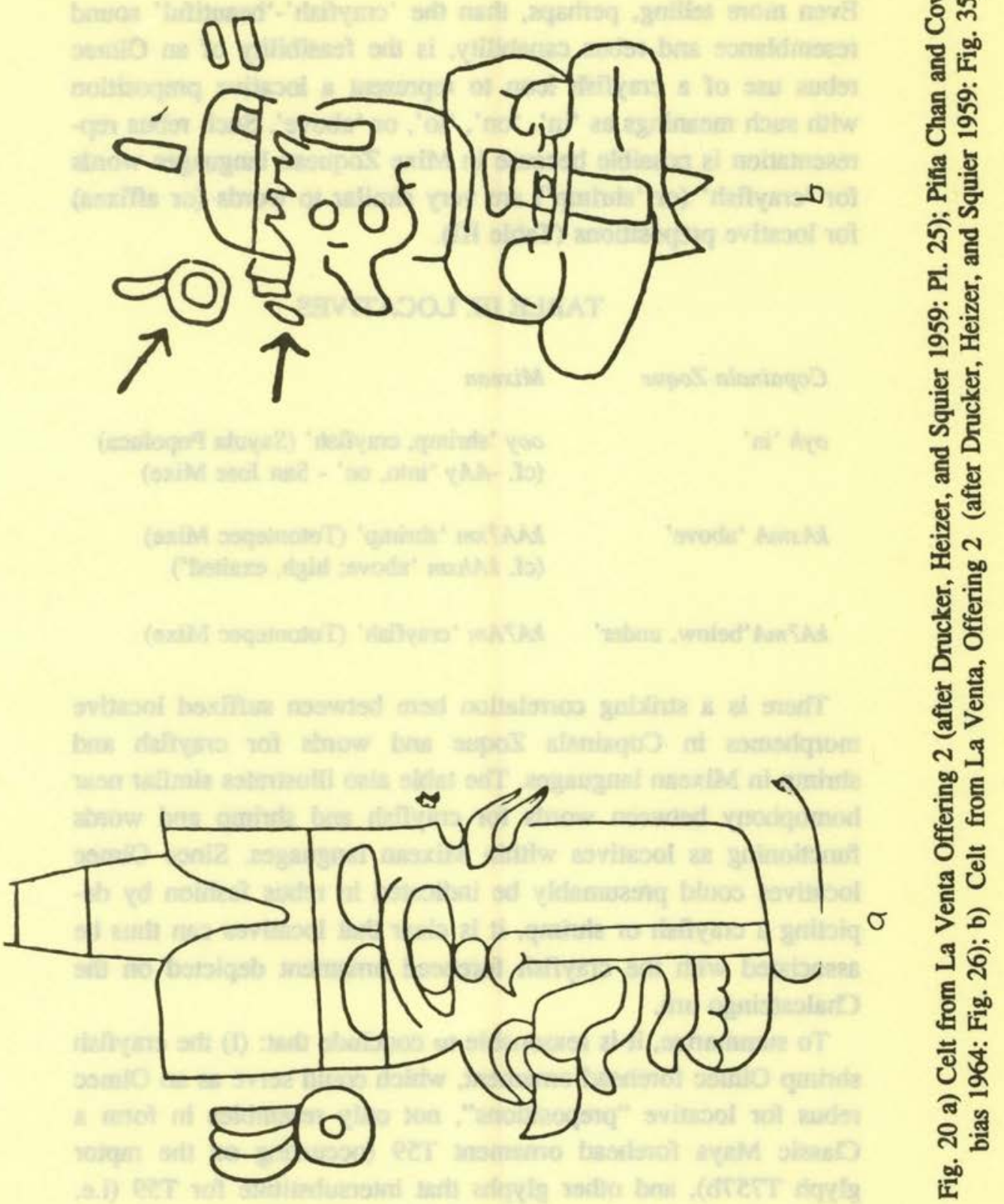


\section{Locative Preposition}

Even more telling, perhaps, than the 'crayfish'-'beautiful' sound resemblance and rebus capability, is the feasibility of an Olmec rebus use of a crayfish icon to represent a locative preposition with such meanings as 'in', 'on', 'to', or 'above'. Such rebus representation is possible because in Mixe Zoquean languages words for 'crayfish' (or 'shrimp') are very similar to words (or affixes) for locative prepositions (Table III).

\section{TABLE III. LOCATIVES}

Copainala Zoque

oyh 'in'

kAsmA 'above'

\section{Mixean}

ooy 'shrimp, crayfish' (Sayula Popoluca)

(cf. -AAy 'into, on' - San Jose Mixe)

kAA? xm 'shrimp' (Totontepec Mixe)

(cf. kAhxm 'above; high, exalted')

\section{$k A$ ? $m A$ 'below, under' $k A$ ? Am 'crayfish' (Totontepec Mixe)}

There is a striking correlation here between suffixed locative morphemes in Copainala Zoque and words for crayfish and shrimp in Mixean languages. The table also illustrates similar near homophony between words for crayfish and shrimp and words functioning as locatives within Mixean languages. Since Olmec locatives could presumably be indicated in rebus fashion by depicting a crayfish or shrimp, it is clear that locatives can thus be associated with the crayfish forehead omament depicted on the Chalcatzingo um.

To summarize, it is reasonable to conclude that: (l) the crayfish shrimp Olmec forehead omament, which could serve as an Olmec rebus for locative "prepositions", not only resembles in form a Classic Maya forehead omament T59 (occurring on the raptor glyph T757b), and other glyphs that intersubstitute for T59 (i.e. 
T51, T53); the forehead omament T59 and its replacements function as locative prepositions as well. This demonstrates continuity of form and function from Olmec times to Mayan times on the one hand. On the other hand, the continuity helps attest to the correctness of the identification of the Olmec forehead omament as a crayfish; particularly so because there seems to be an essentially arbitrary semantic relationship between the notions of 'crayfish' and 'locative'.

It would also be reasonable to conclude that: (2) a symbolic, or semantic connection for the Olmecs, between the concepts 'good/ noble' and/or 'fertility' and the crayfish is demonstrated by the multiple near homophones linking these concepts. There is at the very least, a strongly indicated rebus potential between the words for these concepts as a basis for such connection, and at this point Olmec words similar to a reconstructed *oy, with the meanings of 'crayfish' and 'excellence' appear to be most likely. (3) The formal and structural iconographic similarities between maize and crayfish as well as some evidence of sound similarity in words relating to these concepts additionally points to the notion of 'fertility' as crucially related to the crayfish.

\section{Loan-words}

The second sort of linguistic evidence to be considered here consists of loan-words into Mayan from Mixe-Zoquean languages. Some of this evidence has been presented elsewhere (Stross 1989) and will not be repeated here. Enough evidence of Mixe-Zoquean loan-words in Mayan languages will be given here, however, to indicate the importance of crustaceans (crayfish and shrimp) to the Olmecs and to show the influence of the Olmecs on the Mayans.

\section{Huastecs}

Huastec Mayan tradition has it that the cloud covered mountain within the community of Patnel is guarded by a giant crayfish ( $h i-$ 
ich) living inside it. The crayfish is protecting its water supply (Alcom 1984:79). This close relationship between water and a protector crayfish underscores the watery nature of the environment inhabited by crayfish and recalls the fact that the dotted circlet constituting the bottom part of the Olmec (and Mayan) forhead ornament can refer specifically to water in some Mesoamerican iconographic traditions (e.g. that of the Aztecs).

Huastec Mayans distinguish also a smaller variety of crayfish that lives in wells and is named $\% y$, a word borrowed from a Mixe-Zoquean language. Sayula Popoluca has the word ooy 'crayfish' today, and it was noted above that a similar sounding word was probably used in reference to crayfish during Olmec times. Huastec borrowed the word long enough ago to have created another word oyiyiil 'red' based on the root meaning 'crayfish', and the bright red color of cooked crayfish suggests an observational basis for the word's derivation.

\section{Tzotzil, Tzeltal, and Tojolabal}

In the Tzotzil dialect of San Andres Larrainzar the word masan means 'crayfish'. The word is a borrowing from a Mixe-Zoquean term *masan with the current Zoque reflex masan meaning 'holy, sacred, precious'. The borrowing apparently reflects a perception (whether by Mixe-Zoqueans, Tzotzil Mayans or bilinguals) that the crayfish is at least figuratively 'holy, sacred, or precious'.

In the neighboring Tzotzil dialect of Zinacantan, masan is a transitive verb stem meaning 'to take out a lot of meat from liquid' (Laughlin 1975:230). Anyone who has seined for crayfish knows how apt this semantic description is for the process of crayfish harvesting. The word was borrowed from a Mixe-Zoquean language, perhaps only once by Proto-Tzeltal-Tzotzil, and the meaning it acquired in Zinacanteco Tzotzil suggests an image of farming crayfish in huge quantities, a practice that may have constituted part of the economic base for the population and may have played a part in developing the social organization that allowed for the flowering of the Olmec civilization. 
The Bachajon dialect of Tzeltal, a language very closely related to Tzotzil (Tzeltal and Tzotzil were both the same language not much over 1000 years ago), also has the word masan, borrowed from a Mixe-Zoquean language, but here it means 'shrimp'. Again, borrowing a word for 'holy, sacred, precious' and applying it to a tiny crustacean implies a great deal of respect for that crustacean. ${ }^{9}$

Tojolabal is not so closely related to Tzeltal or Tzotzil as both of the latter are to each other, but it is their neighbor. And it does have the borrowed form masan, although we do not know whether the word was borrowed from a Mixe-Zoquean language or from a Mayan neighbor that had borrowed it from a Mixe-Zoquean language. Tojolabal masan 'to, up to, until, from, since', borrowed ultimately from the Mixe-Zoquean word for 'holy, sacred, precious', does not refer to a crayfish or to any other crustacean. Note, instead, the prepositional-locative nature [temporally focused] of the meaning. This cannot be mere accidental coincidence. It surely indicates meaningful linguistic relationship between the crayfish (or shrimp) and the grammatical function referenced by a (prepositional) locative form; a relationship grounded in the linguistic history of Tojolabal.

With the Tzotzil, Tzeltal, and Tojolabal words here, we seem to have much of the information given above in a nutshell. A MixeZoquean word for 'holy, sacred, precious' ("excellence" in short) is borrowed into one or more Mayan languages. After some time

${ }^{9}$ In Tenejapa Tzeltal, the word masan refers not to the cray fish or shrimp, but rather to the grasshopper, there are other evidences of a "confusion" between the grasshopper and crustaceans in southern Mesoamerica as well, including the fact that Spanish langosta in southern Mesoamerica is frecuently taken to mean 'grasshopper'. Mark and Judy Parsons have brought to my attention what must be the key to this confusion. The grasshopper - like crustaceans such as the crayfish, shrimp, and spiny lobster - turns bright red when cooked. This suggests the additional inference that grasshoppers may well have been cooked and utilized as an important food source in parts of southern Mesoamerica. I have been told by Tzeltal informants that cooked grasshoppers have a nutty taste and are quite good to eat, but that their taste depends to some extent on the species of grasshopper and on the particular plant species that they have dined on. 
has passed, we find in the different Mayan recipient languages that this word has come to mean 'crayfish', 'shrimp', and 'locative preposition'. Clearly, then, the crayfish (and the shrimp) can be linked through investigation of the loan-words to sustenance and fertility, to excellence, and to the locative preposition.

Once more we can conclude that the Olmecs placed a high cultural value on crayfish, and that Mayans today retain fossilized vestiges of this value in their languages. Why was the crayfish so valuable? The answer proposed here is that the crayfish (and shrimp) was an important item in the Olmec diet. Food is one reason for the importance placed on the crayfish by the Olmecs. Fertility symbolism may also have been an important factor. This is nothing new. For example, the Maya maize deity would certainly be considered a fertility deity. There are other reasons to be given below for seeing the crayfish as related to fertility.

In summary, the loan word evidence, like the evidence from Mixe-Zoquean homophony, and the epigraphic evidence supports an association of Olmec and Maya Forehead omaments (originally a crayfish) with (1) sustenance and fertility (2) excellence (e.g. sacredness, preciousness, goodness, nobility, sovereignty, holiness), and (3) locative "prepositions" (in, at, on, to). ${ }^{10}$

A closer look at the nature, distribution, habits, and uses of the crayfish is a necessary prerequisite to an understanding of why the Olmecs might have perceived this animal as good for sustenance, symbolic of fertility, precious, and beautiful. ${ }^{11}$

10 The epigraphic evidence given here omits much, presented elsewhere, that supports the connection of the forehead ornament with the notion of 'sovereignity' and 'nobility' (Stross 1989). It stresses rather the connection of the forehead ornament with crustaceans, with locative function and with a sound value that is focally $o$.

11 The "beauty" of the crayfish may be related to the colors blue (their blood when exposed to the air) and red (their exoskeleton when cooked), the sacred colors of Mesoamerica (related to water and blood respectively), as discussed in Stross (1989). 


\section{Crayfish}

Closely related and visually similar to the lobster, the crayfish is also referred to as crawfish or crawdad in North America. The crayfish, like lobsters, shrimp, and crabs, belongs to the invertebrate class Crustacea. There are more than $\mathbf{4 0 0}$ species of this animal. Occurring in every state of the United States, and all over Middle America, crayfish generally live in freshwater, although a few can be found in brackish or saltwater. Most crayfish in the United States are relatively small, serving primarily as fish bait, although some people eat them. The state of Louisiana, where they grow somewhat larger and are considered a delicacy, produces and consumes about 90 percent of the food crayfish in this country. Many of these are farmed on the more than 100,000 acres of managed crayfish ponds, sometimes in conjunction with a rice crop that may be rotated with soybeans. Crayfish are also farmed in coastal Texas, where they can also be "multicropped" with rice, the stubble of which provides food for the crayfish. ${ }^{12}$

The crayfish head has a sharp snout, eyes on movable stalks, and a hard if thin shell called an exoskeleton that is shed periodically. Showing a preference for silty water and clay soils, the crayfish forages, hunts, and scavenges, feeding on insect larvae, snails, worms, tadpoles, plant roots, and vegetation among other things. The crablike claws and especially the tail of the crayfish are filled with tender, protein-rich meat that to many tastes rather like shrimp, and to others like lobster, only sweeter.

Crayfish are found all over the United States, but they vary in size with different locales, and native perceptions of their utility vary as well. A sample of informants from Tassajara Hot Springs, California, Denver, Colorado, Bismark, North Dakota, Baton

12 Rice has been grown since 1950 in the Coatzacoalcos Basin, the Olmec heartland area of the Isthmus of Tehuantepec, and today rice is an integral part of the local diet. Rice here faces the problem of a "crayfish called the camarón reculador, which flourishes in wetter than normal years and eats the roots of the rice plants" (Coe and Diehl 1980:86). 
Rouge, Louisiana, Dallas, Texas, Austin, Texas, and Beaumont, Texas, all had seen crayfish in their home towns. Some had eaten them. In Dallas, Texas crayfish are for fish bait only, are caught easily by seining silted up shallow tanks, and are caught in great quantities. In Tassajara Hot Springs, Califomia they are plentiful, easy to catch in great numbers, and very tasty eating. In Denver they are small, can be found in great quantity and caught easily in silted up waterways, and they are said to taste like shrimp, though few people eat them. In Beaumont, Texas crayfish and shrimp are farmed, easily harvested, and sold or eaten as a delicacy.

In Baton Rouge, Louisiana crawfish are also farmed and eaten with relish in great quantities. In south central Louisiana lies the semi-wildemess area floodway for the Atchafalaya and Mississippi rivers known as the Atchafalaya Basin. It is from this area, 121 kilometers long and 24 kilometers wide, that more than $10,000,000 \mathrm{lbs}$. of wild crayfish are harvested in some years, the size of the catch depending on water levels and temperatures (Moody 1985).

Louisiana and coastal Texas crayfish are aquatic animals, spending most of their lives in water, though on occasion they can be found walking on land near the water's edge. In late summer or the beginning of autumn female crayfish leave the water to mate and to burrow in the ground. Their burrowing activity creates numerous large conical mounds, or "chimneys", made from balls of

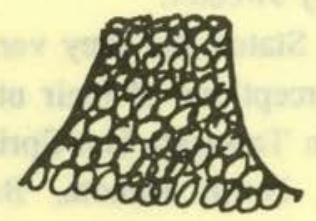

elevation

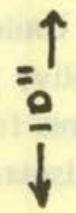

plan

Fig. 21 A crayfish mound or "chimney" drawn from one in Beaumont, Texas. 
muddy clay (Fig. 21). The mounds are a considerable inconvenience to many homeowners, being quite hard, and they can break the blades of a lawnmower. While still burrowed in, the female crayfish will lay her 400 eggs or so, which will hatch in the early spring (Moody 1985:2).

In many parts of Mesoamerica the crayfish is known and eaten. Some of the names by which this animal is known include pigua, chacalin, cambaro, camaya, and acamaya, and mayacaste. They are also commonly referred to as simply camaron 'shrimp', or with specifiers, as in camarón reculador, camarón de agua dulce, camarón de los pozos, camarón de los rios. Information on their habits is scapt, but it is known that they grow wild and are caught and eaten with pleasure by inhabitants of the Isthmus of Tehuantepec, especially the northem portion constituting the Coatzacoalcos River basin. This is in the Olmec heartland region.

It is in the Olmec heartland that the swampy Coatzacoalcos River basin reaps the benefit of the annual ebb and flow of water and silt, and it is here that several species of crayfish are harvested. Coe and Diehl provide some information on crayfish habits and harvest in the Rio Chiquito area near the Olmec site known as San Lorenzo.

"The camaron reculador (Procambarus llamasi and $P$. $r$. ruthve$n i)$ is a crayfish; in the dry season it estivates in holes. but when the rains come it heads for the flooded potreros [savannah pastures with clay base on which alluvium is periodically deposited], when it is taken by both men and women with matayahuales [a circular hand held net for catching shrimp and crayfish]. The male camaron mayacaste, an unidentified crayfish, has claws, which the female lacks. These crayfish are gotten at night on the border of the Rio Chiquito, using a light and a chuzo, during December when the river is falling" (1980:120).

Crayfish as food

Although we know little about the use of Mesoamerican crayfish 
for food, considerably more is known about the crayfish of Louisiana and the Texas coastal area. This delicious tasting animal, even in the wild, yields great quantities of low fat, high protein, easily digestible meat during half of the year with almost no effort involved in catching it. Mesoamerican crayfish conform as well, so far as is known, to this characterization.

Protein. The crayfish is an outstanding source of animal protein, having only about 2 percent fat. Animal protein is particularly necessary when root crops are used as a staple, such as among the Huave, for example, who live on the southem coast of the Isthmus of Tehuantepec and supplement their starchy sweet potato staple food with fish.

Taste. Crayfish meat, coming from the tail area, has what is almost universally, if subjectively, described as a delicious taste. Many say that it is like shrimp, or like lobster but sweeter and more tender. Louisiana natives and many east coastal texans frequently declare that it is the most delightful tasting meat on earth.

Digestability. Crayfish meat is particularly tender, having shorter muscle fibers. Consequently crayfish meat is even more easily digestible than that of lobster.

Ease of harvest. Crayfish are extraordinarily easy to catch as well as being plentiful. Huge quantities of them can be scooped up with just a hand held net or seine. Since they occupy very shallow waters, it is simple for just about anyone of any age to harvest them in great numbers.

Availability. Crayfish reproduce rapidly and grow rapidly in great numbers. Consequently they are plentiful. About 1000 pounds of crayfish can be harvested from a single acre in a year. Of this between 120 and 180 pounds is pure meat from the tail.

Long Season. Live crayfish and fresh tail meat are usually available to Louisiana consumers for a six month period every year. In some areas they are available from November to May; in others from December until June. It remains to be verified that Isthmus of Tehuantepec crayfish have a similarly long period of availability. 
Louisiana crayfish farming

Despite the scarcity of information about the crayfisn in Mesoamerica, it is known that they are utilized for food in the Olmec heartland and in other locations. In the absence of more direct data concerning crayfish farming in the Olmec heartland, ethnographic analogy based on crayfish farming in Louisiana can serve as a tentative guide to some of the principles and possibilities that may have existed in the Olmec heartland.

With more than 100,000 acres of constructed and managed crayfish ponds in Louisiana alone, and many acres also in Texas, crayfish farming is a profitable business: one requiring little investment in time, money, or labor, while yielding rich results. It thus could hold similar potential in another location with similar ecological characteristics, such as the Coatzocoalcos basin in the Olmec heartland area.

Ease of Farming. Crayfish farming can be easily integrated into traditional agriculture. In Louisiana and Southeast Texas many rice farmers get their rice fields to do double duty. After the rice harvest, the rice fields serve as ponds for crayfish. Rice stubble left from the harvest, though usually considered a waste product, serves as food for the crayfish. Re-flooded in September, the rice fields can produce an average of 1,000 pounds of crayfish per acre between November and May. Sometimes soybeans altemate with rice and crayfish in a more elaborate multicropping scheme. Either way, large amounts of crayfish can thus be produced with little time or expense involved. In the Olmec heartland, multicropping of crayfish could not have involved rice or soybeans, of course, as both are Old World plants not found in the Americas before Columbus. It is conceivable that the malanga, maize, or other crop could have been multicropped with crayfish, but there is not evidence in this connection one way or the other.

Clay and Silt. Crayfish thrive in areas of much silt and clay. Crayfish ponds, constructed or natural, should be located in flat open areas of heavy clay soil. Levees should be checked to in- 
sure pond sealing. The levees need to be high enough to hold 18 22 inches of water in the pond, so in general a levee three feet high is sufficient, but a nine foot levee base is important to maintain because of the burrowing activity of the crawfish. In the natural state, periodic flooding brings in the silt in which crayfish thrive, with the many small organisms on which the crayfish can feed, and the enriched productive soil can support vegetal crayfish feed as well. The Olmec heartland area, periodically flooded by nature, has clay soils in the grassy pastures, which helps keep them flooded for the requisite time.

Drainage. Vitally important for crayfish farming, drainage is necessary. (l) To avoid the stress of water with inadequate oxygen, crayfish farmers need to flush or recirculate oxygenated water in ponds. Drainage is needed for this. (2) Sometimes partial drainage is helpful for harvesting the crayfish. (3) Drains are needed to allow for rainfall in regulating the water level. Drains should be matched with the predicted rainfall in the specific location of the pond. A return ditch system with a relift pump has been used successfully by many farmers with a limited water supply. Human labor could of course be used in place of or in conjunction with a mechanical pump. (4) Drains are necessary to allow for pond level variation in order to give an early harvest. By controlling the water level, pond-raised crawfish can be harvested earlier than "wild" crawfish. Artificial drainage such as would be useful in crayfish farming would have to be man-made in the Olmec area, probably in the form of large pipes perhaps with lids, so that they could be cleared of silt periodically. (5) Crayfish farmers need to flush or recirculate oxygenated water in ponds when oxygen levels fall to less than 2 parts per million. Water can be oxygenated to saturation (7-12 ppm) by letting it fall through a series of expanded metal screens as is done on some crayfish farms in Louisiana (LaCaze 1971). It seems probable that this same oxygenating effect could be attained with the use of roughened basalt drain channels for recirculation.

Small Ponds. Small ponds are the best producers and the easiest 
to harvest. Small ponds, that is, smaller than 4.5 hectares, appear to produce more crawfish than larger ponds (Huner 1976). They are also more easily harvested by one person, have better water quality when flooded, and give larger crayfish harvests. In Louisiana some farmers produce about 1500 pounds per acre in small ponds.

Continual Harvest. Daily harvesting during the crayfish season is best for productivity, in order to prevent overpopulation and consequent stunting of the crayfish crop. Pond farmers who trap every day will have at least 50 percent greater production as compared with farmers who only trap on weekends, it has been found.

It can be appreciated now that deliberate crayfish farming involves little investment for large rewards, that smail ponds are not only sufficient, but an advantage, that an artificial drainage system is the most important element in pond management, that a clay base is necessary in crayfish ponds, and that the crayfish harvest is even more productive when it is a daily activity. None of this information indicates that Olmecs were unable to practice crayfish farming. All of it indicates that such farming would have been both possible and economically advantageous for the Olmecs. Some of it provides clues about what to look for in the archaeological record in order to verify Olmec pond management practices that could be referred to as crayfish farming.

\section{Olmec Crayfish Farming}

Apart from the floodplain location and general ecological similarity of the Olmec heartland area to Louisiana's Atchafalaya basin, and the presence in both regions of relatively large edible crayfish that are certainly harvested and eaten in the wild, there are four features in the archaeological record that qualify as evidence supporting the proposition that Olmecs practiced crayfish farming: (1) iconic representation of the crayfish on Olmec portable art; (2) artificial ponds at Olmec ceremonial centers; (3) elaborate roughened drains at Olmec ceremonial centers, and (4) cone shaped mounds at Olmec ceremonial centers. 


\section{Iconic Representation}

This paper began with a discussion of the first feature, focusing on the relatively detailed and more or less naturalistic representation of the crayfish forehead omament on an um from Chalcatzingo. Subsidiary evidence apart from its form was presented above to substantiate both its identification as a crayfish and the importance of the crayfish to the Olmecs.

The fact that the most naturalistic iconographic evidence of the crayfish depicted on Olmec portable art comes from Chalcatzingo, a highland site not in the Olmec heartland, does not detract significantly from the argument. (1) Crayfish also live in Morelos and could have been farmed there; and in fact large yields of Morelos crayfish would probably require farming them whereas the heartland area has plenty of large wild ones. (2) The Chalcatzingo urn is portable and could have been imported from the lowlands, just as could the naturalistic representation of what may well be a crayfish tail replacing a tongue (or growing from the chin) on an Olmec pottery vessel from Tlapacoya in the Valley of Mexico (Fig. 22). ${ }^{13}$ (3) Even non-portable art in the Mesoamerican highlands can portray items more appropriate to the lowlands. Jaguars painted on Teotihuacan murals constitute one example. Another example is the malanga (Xanthosoma species) plant atop a ruler's headdress on Kaminaliuyu Stela 11, when the malanga is a far more important root crop in the riverine lowlands. (cf. Fig. 23).

\section{Olmec Ponds}

Recalling the fact that crayfish thrive and produce better harvests in small ponds, and noting the importance of clay where crayfish

13 Joralemon (1971:83) reproduces, in his Fig. 248, Painting 2 from Juxtlahuaca, Guerrero, in which a serpent is depicted with both tongue and tail ending in three-pronged elements similar to that on the Tlapacoya vessel referred to here. Thus a tongue identification for what is replaced on the Tlapacoya vessel seems warranted. 


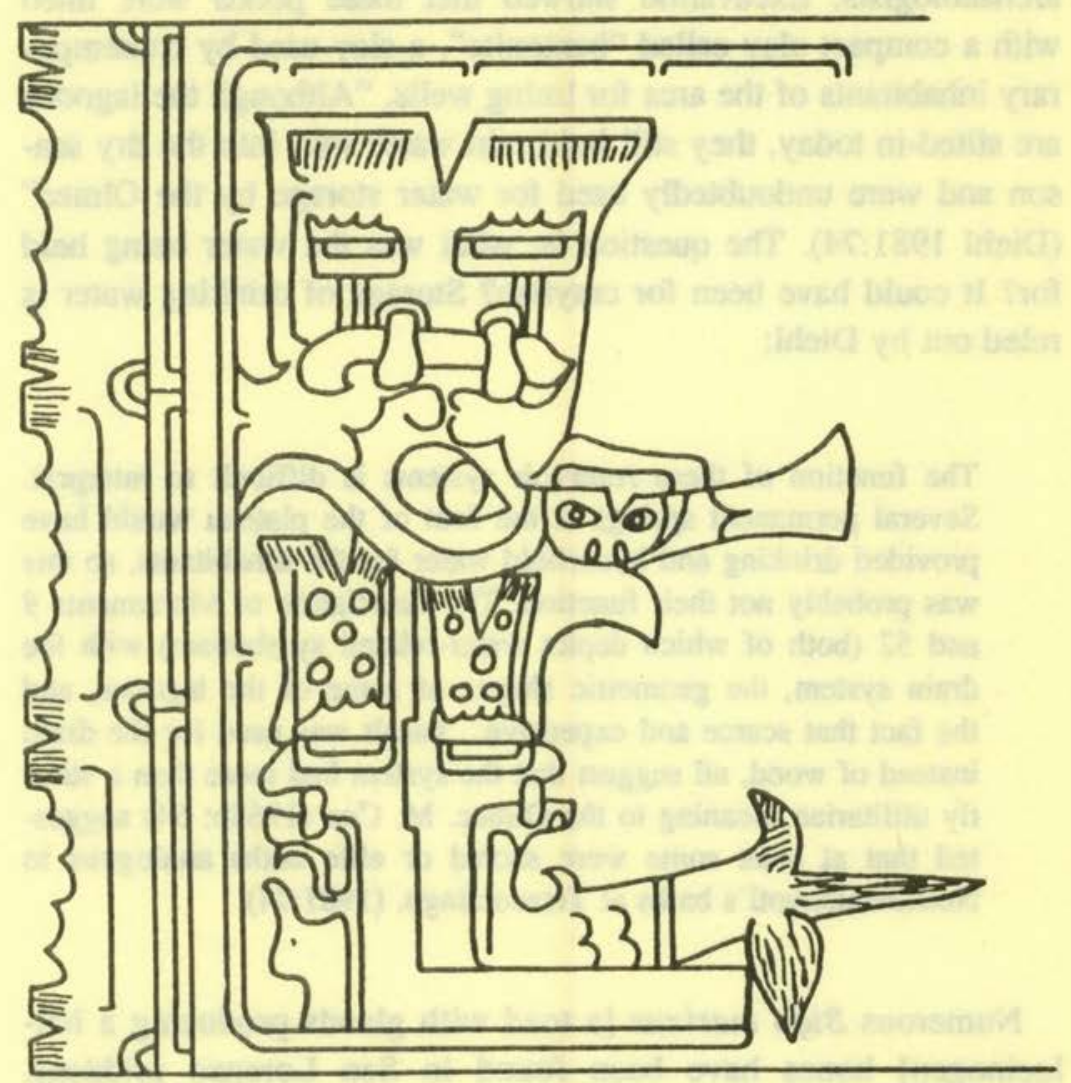

Fig. 22 Olmec vessel from Tlapacoya (after Joralemon 1971:Fig. 146) 
ponds are located for farming, the discovery of small shallow ponds at the Olmec site of San Lorenzo appears to have considerable significance for the hypothesis presented here (Fig. 24).

Located on the San Lorenzo ridge in the central area of San Lorenzo, some twenty small lagunas (ponds) have been found by archaeologists. Excavation showed that these ponds were lined with a compact clay called "bentonite", a clay used by contemporary inhabitants of the area for lining wells. "Although the lagoons are silted-in today, they still hold rain water well into the dry season and were undoubtedly used for water storage by the Olmec" (Diehl 1981:74). The question is, what was the water being held for? It could have been for crayfish? Storage of drinking water is ruled out by Diehl:

The function of these reservoir systems is difficult to interpret. Several permanent springs at the foot of the plateau would have provided drinking and household water for the inhabitants, so this was probably not their function. The association of Monuments 9 and 52 (both of which depict water-related symbolism) with the drain system, the geometric shapes of some of the lagoons, and the fact that scarce and expensive... basalt was used for the drain instead of wood, all suggest that the system had more than a strictly utilitarian meaning to the Olmec. M. Coe (1968b: 64) suggested that at least some were sacred or elite baths analogous to Netzahualcoyotl's baths at Tetzcotzingo. (1981:74)

Numerous Bufo marinus [a toad with glands producing a hallucinogen] bones have been found in San Lorenzo middens. prompting Furst to suggest the possibility that such toads may have been kept under direct observation in ritual captivity by the Olmecs there "perhaps as avatars of the divine earth" (1981:158). The ponds could have been employed for that purpose, but it is doubtful.

The ponds at San Lorenzo could have functioned just as easily as homes for crayfish, either so that they could be kept under 


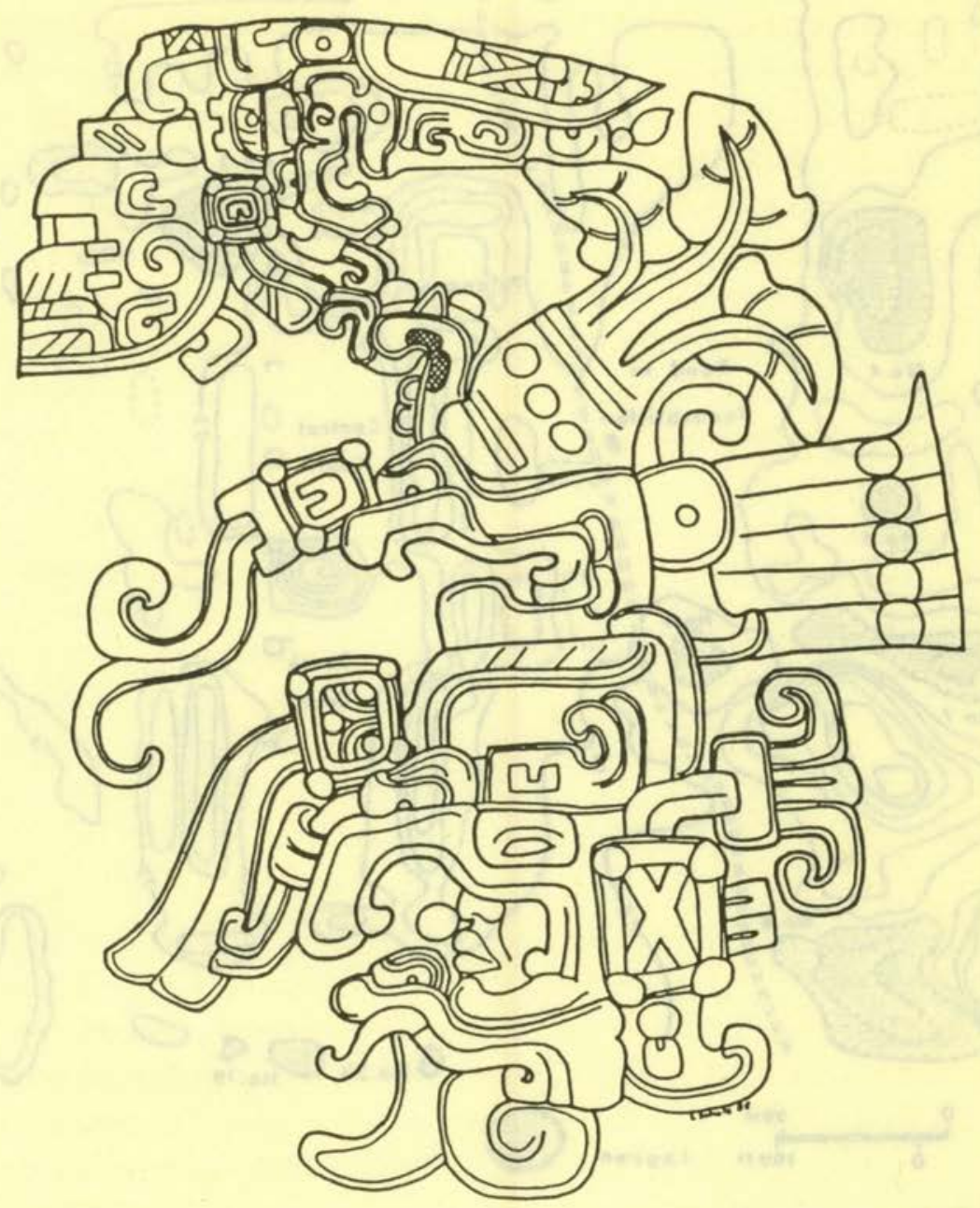

Fig. 23 Detail of Kaminaljuyu stela 11: (after Cortez 1984) 


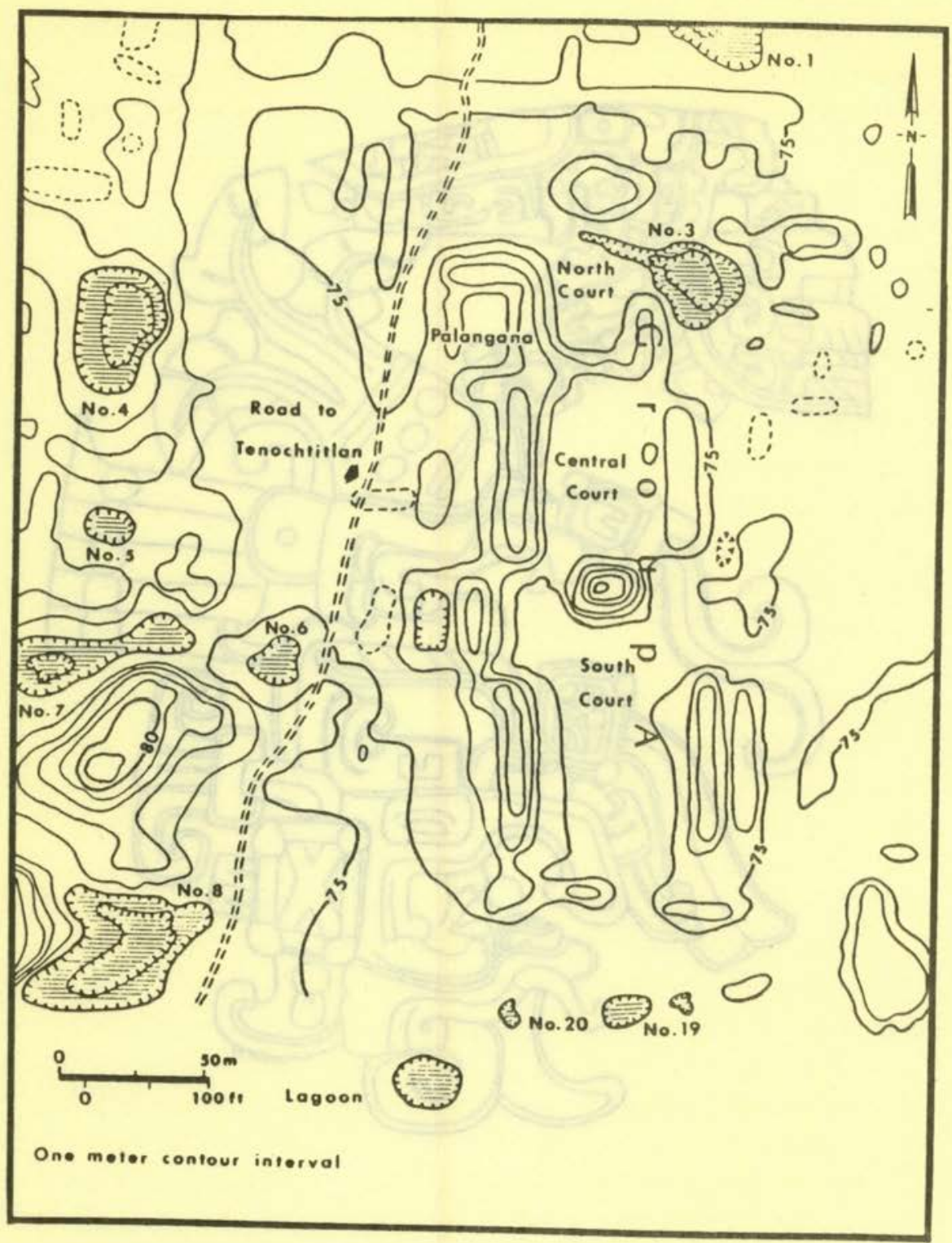

ig. I Plan of the central section of San Lorenzo. Map by T. Majewski (modified from M. Coe t967a: map in
rocket).

Fig. 24 Plan of central section of San Lorenzo (after Diehl 1981:71)

Estudios de Cultura Maya. Vol. XIX, 1992

Instituto de Investigaciones Filológicas/

Centro de Estudios Mayas, UNAM

ISSN 0185-2574 
observation in ritual captivity, or as a source of excellent (or ritually pure or sacred) food for the noble and or priestly Olmec population of the site. It is the drains in the ponds that reinforce this conclusion, for crayfish require such drainage whereas Bufo marinus doesn't.

\section{Olmec Drains}

The drainage systems associated with the artificial ponds on the plateau top at San Lorenzo are extraordinary. They are made of large $U$ shaped basalt troughs with slightly convex covers, forming long conduits. Tremendous quantities of stone, brought from long distances and worked with great labor expenditure, are involved in the construction of these conduits. A single drain of some 600 feet required more than 30 metric tons of carefully worked basalt stone; and this is just one part of a more extensive drainage system. The drains were in three flood deep trenches left open during the period in which the system was functioning, perhaps so that silt could be removed more easily.

Such long basalt conduits would have been able to oxygenate water as well as to flush it. If the water was to be recirculated, such oxygenation would have been necessary. A retum ditch system, evidenced by one end of a drain ending up near the other, would be solid evidence that the drains were being used for oxygenation and recirculation. Lack of this feature is not negative evidence, however, in an area where water is relatively plentiful. River water, already oxygenated, could have been used to replenish the water supply of the ponds when they were flushed.

San Lorenzo, whose drains were used relatively early in the site's occupation, is not the only Olmec site with such drains. Similar $\mathrm{U}$ shaped troughs of basalt functioned as drains at $\mathrm{La}$ Venta (Diehl 1981), and at the site of Teopantecuanitlan in Guerrero. ${ }^{14}$ This latter site, located in a rugged mountainous area near

$14 \mathrm{U}$ shaped stone drains have also been found at Teotihuacan, where it is suggested that water was ceremonially drained into the cave underlying the 
the juncture of the Mezcala and Amacuzac river drainage system. has what are probably the earliest stone drains and stone aqueduct in North America.

Since drains are needed to farm crayfish away from floodlands, for flushing, for re-oxygenation, and to regulate the water level (for control of harvesting among other things, their presence at the Olmec sites of La Venta, San Lorenzo, and especially Teopantecuanitlan is suggestive).

Clearly the drains are too elaborate and labor expensive, and the ponds too few at the Olmec ceremonial centers, for us to interpret them in purely functionally economic terms. These ponds and drains could have had powerful ritual significance, however, recalling, for example, the miniature rice fields next to the Japanese emperor's palace. Each year the emperor goes through the motions of planting rice, symbolic of the planting of all the ricefields in the lands under his dominion, so as to ensure the successful planting and harvest from all the rice fields cultivated by his subjects. Such control of earthly phenomena by means of sanctified miniature ritual icons representing them can be found in many societies of the world and would seem to be close enough to a universal human impulse that the suggestion of similar behavior by Olmecs with respect to the crayfish in ceremonial centers is not inherently far fetched.

\section{Olmec Conical Mounds}

One interesting habit of the crayfish, it will be recalled, is the building of cone shaped mounds or "chimneys" for nesting (cf. Fig. 21). Artificial mounds are found at San Lorenzo (Diehl 1981), and artificial earth mounds will probably be reported for many Olmec sites in the heartland area. A 90 foot high fluted conical earth mound at La Venta is one of the wonders of Mesoameri-

Pyramid of the Sun, perhaps as part of a ritual complex pertaining to the emergence of mankind (Taube 1986:54). 
ca (Fig. 25). Guerrero's Teopantecuanitlan is nestled in the shadow of a conical hill. This does not exhaust the cone shapes either. The Chalcatzingo um is cone shaped, quite similar, with its hole in the top and general shape, to the "chimney" built by the female crayfish in which to lay her eggs.

It has been speculated by some that La Venta's conical earth "pyramid" of Complex C was built in imitation of the sometimes fire belching conical peaks known as volcanoes, such as those found to the north in the Tuxtla Mountains and next to Lake Catemaco (cf. e.g. Luckert 1976:41-43). Volcanoes are well known, not only for their incredible power, but also for the fact that volcanic eruptions greatly increase the fertility of the surrounding land after a few years, as soluble mineral nutrients are leached out of the ground, and fertile volcanic ash settling in the vicinity of a volcano is known to attract planters from far away (Luckert 1976:46).

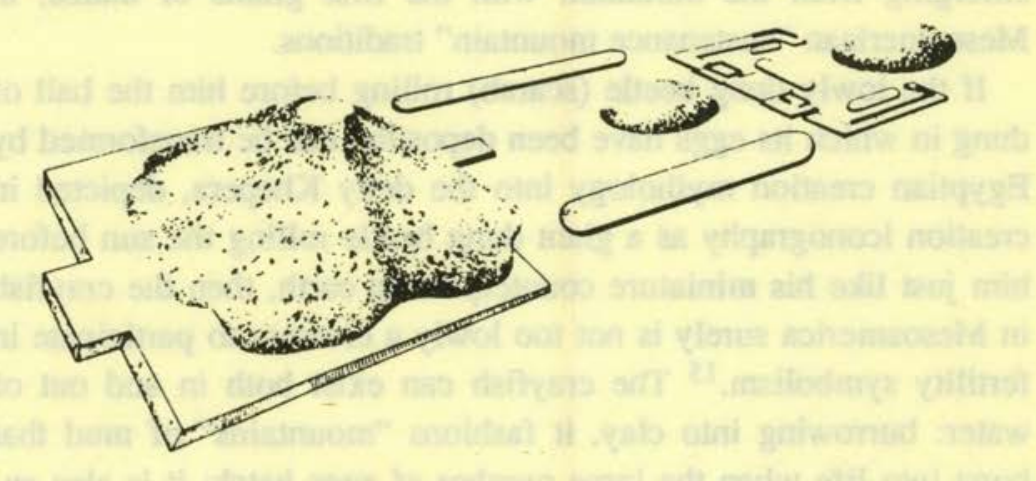

Fig. 25 Fluted conical mound at La Venta Complex C (after Coe 1977) 
Any cone shaped mound, particularly with a hole in the top, perhaps in imitation of fertile volcanic peaks, might easily be seen as a fertility symbol. And in Mesoamerican oral tradition as well as iconography, the mountain as a source of food and of water is well known (cf. Stross 1987). According to the Aztecs, maize was stored in "sustenance mountain" until liberated for use by humanity. Likewise various Mayan societies of today have traditions ascribing the liberation of maize from a mountain in order to sustain humans. The Quiche refer to this mountain by the name Paxil, which means 'split open'.

But volcanoes are not the only mounds independently associable with fertility. The conelike "chimneys" of crayfish, slowly built up from little balls of clay mud, and having holes in their tops, and containing 400 or more eggs that will hatch into crayfish larvae, could easily symbolize fertility to a people perceiving the crayfish as sustenance. Moreover in a convergence resulting in mutual symbolic reinforcement, crayfish mounds could also be visualized as just like miniature volcanos, just as are ant mounds (known as "ant caves") today among the Sierra Popoluca, a Zoquean speaking people living in the Olmec heartland near Lake Catemaco (Kay Sammons, p.c. 1988), recalling the role of ants, emerging from the mountain with the first grains of maize, in Mesoamerican "sustenance mountain" traditions.

If the lowly dung beetle (scarab) rolling before him the ball of dung in which its eggs have been deposited can be transformed by Egyptian creation mythology into the deity Khepera, depicted in creation iconography as a giant dung beetle rolling the sun before him just like his miniature counterpart on earth, then the crayfish in Mesoamerica surely is not too lowly a creature to participate in fertility symbolism. ${ }^{15}$ The crayfish can exist both in and out of water: burrowing into clay, it fashions "mountains" of mud that burst into life when the large number of eggs hatch; it is also su-

${ }^{15}$ Khepera, the Egyptian deity simbolized by a dung beetle, is in essence a creation deity symbolic of matter about to come into a state of activity. 
premely edible and nutritive. Surely it makes an excellent fertility and sustenance symbol, emphasizing creation as well as procreation.

The crayfish mound, if not alone explanatory of the earth mound symbolism to be found at Olmec archaeological sites, may well exemplify and reinforce it, and may have played a part in the creation of this symbolism and its particular modes of manifestation.

In summary, this section has discussed four products of Olmec labor to be found in the archaeological record at Olmec sites; crayfish depictions on portable art, ponds, drains, and mounds. No single one of these represents compelling evidence that the Olmecs practiced crayfish farming in anything like the way it is currently practiced in Louisiana and Southeast Texas, but all are consistent with such practices and with cultural traditions that might arise as a result, and these features in the archaeological record are consonant with, and can be explained in terms of, an economy in which crayfish pond management and harvesting are present. In conjunction with the evidence of crayfish importance to Olmecs derived from iconography, epigraphy, and language data, and the evidence that crayfish are significantly present in the Olmec heartland, and the ability of such a protein source to help explain some of the population and other characteristics inferred from Olmec remains, it seems that there is substantial motivation for the hypothesis that Olmecs practiced crayfish farming.

\section{Conclusion}

For years some archaeologists were saying that the ancient Maya couldn't have raised such impressive cities with a population base supported simply by slash and burn maize farming with the attendant need for fallowing. Raised fields have been discovered in some parts of the Maya lowlands, and ramon nuts have been suggested as storable and nutritious supplements to the diet, while 
root crops (e.g. sweet potatoes, malanga, manioc, yams) were suggested as altemative staples whose yield in pounds per acre could be many times that of maize. These low protein root crops require protein rich supplements, such as fish, crustaceans, or other animal flesh, (Culbert 1974:45-50). The agricultural picture became more complex in recent years with the discovery that in some areas at least, the Maya utilized raised maize fields with naturally attendant shallow waterways and might have come near to fully exploiting their multicrop pisciculture potential. It seems likely that crayfish constituted a significant part of that ecosystem, whether on a lower or a higher level in the food chain. They may even have been farmed in the Olmec heartland.

Adams argues that the Olmec population, if slash and bum agriculture was their dominant subsistence means, would necessarily be dispersed, resulting in the development of civic centers that were virtually deserted for most of the year and occupied by only a small elite class with its supporting population (1977:83). And indeed an estimate of San Lorenzo's live-in population is given as only 1000 (Adams 1977:84). It is difficult, however, to imagine successful coordination of the communal activities of the many thousands of Olmecs that would have been required for constructing and maintaining the ceremonial centers unless they lived relatively close by and relatively close to one another; they could not have been nearly so dispersed as swidden cultivation would lead one to expect.

Of course the heartland Olmec would not have had to rely on slash and burn maize cultivation alone. "Certainly the rivers, oxbow ponds and seasonally flooded potreros [pasturelands] provide the people of the area [around San Lorenzo in the Olmec heartland] with a diet extraordinarily rich in animal protein. We have the feeling that the local people are among the best nourished in all of Mesoamerica" (Coe 1981:123).

There is also some evidence that root crops, and particularly the malanga, were more widely utilized in the past (Coe and Diehl 1980:85). Since root crops would require an animal protein sup- 
plement, and any diet can profit from an animal protein supplement, it is suggested that crayfish seine harvesting in the wild, and even crayfish farming could have provided a part of that supplement for the Olmecs at some stage in their history. Thus they could have maintained higher population densities, allowing them to have evolved the complex social organization that they apparently had, and to construct the elaborate ceremonial sites and objects for which they are famous.

The Olmecs may have practiced crayfish farming in lagoons formed by levees on the flood plain, accompanied by specially constructed shallow ponds in ceremonial centers as ritually symbolic prototypes, and in shallow canals integrated with some form of root crops and/or raised field maize agriculture. It has been here suggested that crayfish farming may explain the clay lined ponds and elaborate drain systems as well as the conical peaks or pyramids found at some Olmec sites; it could have provided a rich source of protein to supplement root crops and/or maize for support of the substantial local population and the complex social organization characterizing the Olmec civilization; and it could explain the apparent interest in the crayfish shown in Olmec iconography and language.

It is conceivable that crayfish pond management and planned harvesting was specifically for the Olmec elite. Clearly the few ponds on the central portion of the site of San Lorenzo would not by themselves support many persons. They are more likely to have been symbolic references to fertility as an aspect of Olmec religious life, and may well have held crayfish. They likely were also ritual references to Olmec origins, vital ceremonial paraphernalia for the creation, by means of miniature landscapes, of sacred space and time.

Clearly crayfish farming, and hence the use of crayfish symbols did not recognizably persist in Mesoamerica. That is to be expected, just as many of the symbolic vehicles in Mesoamerican tradition varied somewhat from culture to culture, and within a single cultural tradition transformed themselves over time. Yet one might 
expect to find some more obvious traces of crayfish farming in later Mesoamerican iconography. Perhaps the traces are there, but not yet recognized; or perhaps the crayfish was truly phased out as a viable symbol when new environmental constraints or new agricultural resources came into play.

One ecological factor that could have contributed to the demise of crayfish farming among Olmecs is suggested by modern experiences with crayfish. Several years ago in East Texas a virus got into the crayfish breeding grounds, making the crayfish inedible. This effect lasted for two or three years (Dana Moore, p.c. 1988). Such virus attacks could even help to account for a phasing out of particular Olmec sites, perhaps not because of a dependence on crayfish, but possibly for reasons more closely connected to ritual and religious practices related to the crayfish as a fertility symbol.

The main thesis of this paper stems from a conclusion already reached (Stross 1989) that the crayfish was important to the Olmecs, and was used as (a) a rebus and (b) a fertility and/or power symbol. Arguments partially summarized in the current paper involve several lines of evidence, including an association of Maya forehead ornaments and headdress with fertility and sustenance, with sovereignty and power, and with the locative grammatical function. Loan-words in Mayan languages suggest the importance of crustaceans to the Olmecs and the influence of the Olmecs on the Mayans. Independent homophones (near homophones) for 'good/exalted/noble' and 'crayfish/shrimp' in Mixe-Zoquean languages indicate some lasting Olmec association between the concepts, due wholly or in part to rebus usage in Olmec iconography which could have arisen originally either on the basis of an accidental homophony or on the basis of some ecologically motivated cultural perceptions by the Olmecs. Mixean and Zoquean sound similarities between words for crayfish and words for different locatives, link the crayfish to locative prepositions. Mixean and Zoquean sound similarities between words for crayfish and words for maize (allowing for rebus potential). Corroborating this association of the crayfish with importance for the Olmecs is the actual 
depiction of the crayfish on Olmec portable art in the relevant structural position. The remainder of this paper has examined archaeological evidence in the light of modern ethnographic and ecological analogy in order to sustain motivation for the hypothesis that Olmecs practiced crayfish farming. It is seen here to be a good explanatory hypothesis awaiting further investigation and corroboration.

\section{REFERENCES CITED}

AdAMs, RichaRd E. W.

1977. Prehistoric Mesoamerica. New York: Little, Brown \& Co. ALCORN, JANIS

1984. Huastec Mayan Ethnobotany. Austin: University of Texas Press.

AtTenBorough, DAVID

1976. The Tribal Eye. New York: W. W. Norton and Co.

AulIE, WLbUR and EvelyN

1978. Diccionario Ch'ol. Mexico City: Summer Institute of Linguistics.

BENSON, Elzabeth P. (ed.)

1981. The Olmec and Their Neighbors. Washington, D.C.: Dumbarton Oaks.

BERNAL, IGNACTO

1969. The Olmec World. Berkeley: University of California Press.

CAmpbell, Lyle and Terrence Kaufman

1976. "A linguistic look at the Olmecs." American Antiquity 41:80-89.

Clark, Lawrence

1981. Diccionario popoluca de Oluta. Mexico City: Summer Institute of Linguistics.

and NANCY D. Clark

1974. Vocabulario popoluca de Sayula. Mexico City: Summer Institute of Linguistics. 
Coe, Michael D.

1977. Mexico (Second Edition). New York: Praeger Publishers. and Kent V. Flannerey

1964. "Microenvironments and Mesoamerican Prehistory." Science 143:650-654.

- and RichARD A. DIEHL

1980. In The Land of the Olmec, 2 Volumes. Austin: University of Texas Press.

Coggins, Clemency Chase and Orrin C. Shane III

1984. Cenote of Sacrifice. Austin: University of Texas Press.

Culbert, T. Patrick

1974. The Lost Civilization: The Story of the Classic Maya. New York: Harper and Row.

DIEHL, RichaRd A.

1981. "Olmec architecture: a comparison of San Lorenzo and La Venta." in E.P. Benson, ed., The Olmec and Their Neighbors. Washington, D.C.: Dumbarton Oaks.

EDMONSON, MUNRO

1965. Quiche-English Dictionary. New Orleans: M.A.R.I. Gay, CarLo T.E.

1971. Chalcatzingo. Graz: Akademische Druck-u. Verlagsanstalt. FURST, PETER

1981. "Jaguar baby or toad mother. a new look at an old problem in Olmec iconography." in E.P. Benson, ed., The Olmec and Their Neighbors. Washington, D.C.: Dumbarton Oaks.

Grove, David C.

1987. Ancient Chalcatzingo. Austin: University of Texas Press.

Harrison, Roy and Margaret, and Castulo Garcia H.

1981. Diccionario zoque de Copainala. Mexico City: Summer Institute of Linguistics.

Harrison, Roy and Margaret, Lopez JuÁrez, Francisco and Cosme OrDOFFES

1984. Vocabulario zoque de Rayon. Mexico City: Summer Institute of Linguistics.

HUNER, J. V.

1976. "Raising crawfish for fresh bait and food: a new polyculture crop with fish." The Fisheries Bulletin 1:7-9.

Joralemon, Peter DAVID

1971. A Study of Olmec Iconoqraphy. Washington, D.C.: Dumbarton Oaks . 
JUSTESON, JOHN S.

1984. "Interpretations of Mayan hieroglyphs" in J. Justeson and L. Campbell (eds.) Phoneticism in Mayan Hieroglyphic Writing. Institute of Mesoamerican Studies. Publication \#9. S.U.N.Y. Albany.

Justeson, JoHn AND L. CAMPBell (eds.)

1984. Phoneticism in Mayan Hieroglyphic Writing. Institute of Mesoamerican Studies. Publication \#9. S.U.N.Y. Albany.

LaCaze. Cecil

1971. "Crawfish Farming." (Revised Edition) Louisiana Wildlife and Fisheries Commission, Fisheries Bulletin No. 7. (27 pp.)

LAUGHLIN, ROBERT M.

1975. The Great Tzotzil Dictionary of San Lorenzo Zinacantan. Washington, D.C.: Smithsonian Institution Press.

LUCKERT, KARL W.

1976. Olmec Religion. Norman: University of Oklahoma Press.

Mathews, PETER and John Justeson

1984. "Patterns of sign substitution in Maya hieroglyphic writing: 'the affix cluster"'. in J. Justeson and L. Campbell (eds.) Phoneticism In Mayan Hieroglyphic Writing. Institute of Mesoamerican Studies Publication \#9. S.U.N.Y. Albany.

MARCUS, JoYcE

1980. "Zapotec writing." Scientific American 244:50-64. MiLLON, ReNe

1981. "Teotihuacan: city, state, and civilization." in V. R. Bricker, ed., Supplement to the Handbook of Middle American Indians. Austin: University of Texas Press.

MoOdY, Michael. W.

1985. "Louisiana seafood delight: the crawfish." Louisiana Cooperative Extension Service, Sea Grant Publication -LSU-TL-80-002- Louisiana State University Agricultural Center.

NORMAN, V. Garth

1976. Izapa Sculpture. (Part 2: Text). Provo: New World Archaeological Foundation.

Sánchez CAstro, Alejandro

1947. Luis Nicolas Guillemaud: interesante historia de un buen francés que vino a Mexico en 1830. Los mixes: historias, leyendas, musica. Mexico D.F. La Impresora. 
SCHOENhals, AlVIN and Louise C.

1965. Vocabulario mixe de Totontepec. Mexico City: Summer Institute of Linguistics

Slocum, Marianna C. and Florence L.

1965. Vocabulario tzeltal de Bachajon. Mexico City: Summer Institute of Linguistics

Stross, Brian

1989. "Olmec Vessel With A Crayfish Icon: An Early Rebus." in W. Hanks and D. Rice (eds), Word And Image In Maya Culture: Explorations In Language, Writing, And Representation. Salt Lake City: University of Utah Press. pp. 143164.

1987. "Ancestral Squirrel Mountain." (unpublished manuscript, Dept. of Anthropology, U. of Texas)

Swadesh, Mauricio, Ma. Cristina Álvarez, and Juan R. Bastarrachea.

1970. Diccionario de elementos del maya yucateco colonial. Mexico City: U.N.A.M., Centro de Estudios Mayas.

TAUBE, KarL A.

1986. "The Teotihuacan cave of origin." Res: Anthropology and Aesthetics 12:51-82.

VAN HaITSMA, JULIA and WILLARD

1976. A Hierarchical Sketch of Mixe. Mexico City: Summer Institute of Linguistics. 